\title{
Review
}

\section{Primary innervation of the avian and mammalian cochlear nucleus}

\author{
David K. Ryugo $^{\mathrm{a}, *}$, Thomas N. Parks ${ }^{\mathrm{b}}$ \\ ${ }^{a}$ Departments of Otolaryngology—Head and Neck Surgery and Neuroscience, Johns Hopkins University School of Medicine, \\ Baltimore, MD 21205, USA \\ ${ }^{\mathrm{b}}$ Department of Neurobiology and Anatomy, University of Utah School of Medicine, Salt Lake City, UT 84132, USA
}

Received 15 April 2002; received in revised form 8 November 2002; accepted 15 January 2003

\begin{abstract}
The auditory nerve of birds and mammals exhibits differences and similarities, but given the millions of years since the two classes diverged from a common ancestor, the similarities are much more impressive than the differences. The avian nerve is simpler than that of mammals, but share many fundamental features including principles of development, structure, and physiological properties. Moreover, the available evidence shows that the human auditory nerve follows this same general organizational plan. Equally impressive are reports that homologous genes in worms, flies, and mice exert the same heredity influences in man. The clear implication is that animal studies will produce knowledge that has a direct bearing on the human condition.
\end{abstract}

(C) 2003 Elsevier Science Inc. All rights reserved.

Keywords: Brain; Hearing; Neurons; Synapses; Transmitters

\section{Introduction}

Adaptations for specialized hearing are impressive and widespread among vertebrates. As a result, auditory neurobiology has benefited greatly from the application of a variety of research techniques to understand structure-function relationships in a range of species. The unique advantages that particular species offer have allowed the development of useful animal models for study of both normal and pathologic aspects of human hearing. Birds and mammals, both endothermic amniotes, share sophisticated abilities to generate complex sounds for communication and to use their hearing as a means to locate and identify potential mates, predators, and prey. Although mammals and birds last shared a reptilian ancestor more than 200 million years ago $[8,34]$, it has often been informative to examine how similar auditory problems are solved by representative modern birds and mammals. These research programs often begin by analyzing how a particular feature of an animal's hearing is integral to its ecology and evolutionary history and then seek to understand how derived features of the auditory system serve specific hearing functions. This approach has identified important features common to brain development and

* Corresponding author. Tel.: +1-410-955-4543; fax: +1-410-614-4748.

E-mail address: dryugo@bme.jhu.edu (D.K. Ryugo). function in the terrestrial vertebrates and it appears that the comparative approach will continue to be productive [33].

This review will compare what is known about the projection of the auditory nerve onto the brainstem auditory nuclei in birds and mammals with the intent of highlighting biologically significant similarities and differences. The auditory nerve conveys environmental acoustic information to the brain by taking the output of the sensory hair cells in the inner ear and distributing it to various target neurons in the cochlear nuclei.

\section{Birds}

In birds, the auditory nerve enters the lateral aspect of the brain stem and terminates in the cochlear nuclei angularis and magnocellularis (chicken and penguin, [17,140,151]). Individual fibers are myelinated, their diameter increases with increasing $\mathrm{CF}$ up to about $7 \mathrm{kHz}$ in the barn owl [91], and they arise from a population of ganglion cells that is homogeneous in comparison with mammalian spiral ganglion neurons (chicken, [52]; barn owl, [92]). In the absence of experimenter-controlled stimulation, single auditory nerve fibers give rise to irregularly occurring spike discharges. All acoustically responsive fibers exhibit spontaneous spike discharges (SR) that range from 0 to 200 spikes per second 
[92,109,181,182]. Although different rates of SR have been observed among birds (e.g. chickens, starlings, barn owls), they appear to have a unimodal SR distribution [92]. One of the fundamental features of auditory neurons is their preference for a particular frequency of stimulation, and it may be described by a threshold-tuning curve. A tuning curve describes the level and frequency coordinates of a neuron's response area to tonal stimuli. The tip of the tuning curve reveals the single frequency to which the neuron is most sensitive, and defines its characteristic frequency (CF). Tuning curves tend to be symmetrical, and a fiber's CF is determined by its innervation place in the basilar papilla [36]. Low-frequency fibers arise from the apex, and fibers with increasing CFs arise from correspondingly more basal regions. Avian primary auditory neurons appear comparatively uniform in their morphology and response properties, differing primarily in their $\mathrm{CF}$. The central projections of auditory nerve fibers also exhibit relatively stereotypic structure (pigeon, [17]; barn owl, [29]). Upon entering the brain stem, fibers divide to form a thinner lateral branch and a thicker medial branch, and send the resulting branches into the two divisions of the avian cochlear nucleus, nucleus angularis and nucleus magnocellularis (Fig. 1).

\subsection{Nucleus angularis (NA)}

\subsubsection{Innervation}

The lateral branch emerges in the nerve root and projects dorsally and rostrally to terminate in the NA. As the lateral branch proceeds into nucleus angularis, it gives rise to one or more thin collaterals. These thin collaterals ramify and give rise to en passant swellings and small boutons in a "minor" terminal field near the site of entry of the lateral branch. The main lateral branch continues rostrally and arborizes to form a "major" terminal field, ending as a spray of en passant swellings, and simple and complex swellings ([29]; Fig. 2). There is a systematic relationship between fiber $\mathrm{CF}$ and its terminal field in NA, such that there is a tonotopic order where high-CF fibers are found dorsal to lower $\mathrm{CF}$ fibers (sparrow, [89]; barn owl, [93]).

\subsubsection{Cellular organization}

The cell types in NA represent a heterogeneous mixture that has been defined as bipolar or multipolar cells on the basis of size and dendritic characteristics $[69,188]$. Planar and stubby cells have dendrites restricted within isofrequency planes, whereas radiate cells and bipolar (or vertical) cells extend their dendrites across the isofrequency planes (Fig. 2B from [188]). Cell density was related to the tonotopic axis of the nucleus, with the high-frequency regions of the nucleus exhibiting the higher density of cell packing. Lower frequency regions had lower cell packing density. Although the resident cells exhibit varied morphology, their response to $\mathrm{CF}$ tone stimulation was almost exclusively the "transient chopper" pattern with very regular spike discharges [197]. These units typically have low SRs, large dynamic ranges characterized by progressive increases in spike discharges with increasing stimulus intensities and high-saturation levels, and little or no tendency to respond in phase to a sinusoid [198,214]. These results have led to the proposal that NA is specialized to process intensity cues [198,200,214].

\subsubsection{Transmitters and receptors}

As in other portions of the ascending auditory system in mammals and birds, the AMPA subtype of ionotropic glutamate receptor mediates rapid synaptic transmission in nucleus angularis. Rapidly desensitizing AMPA

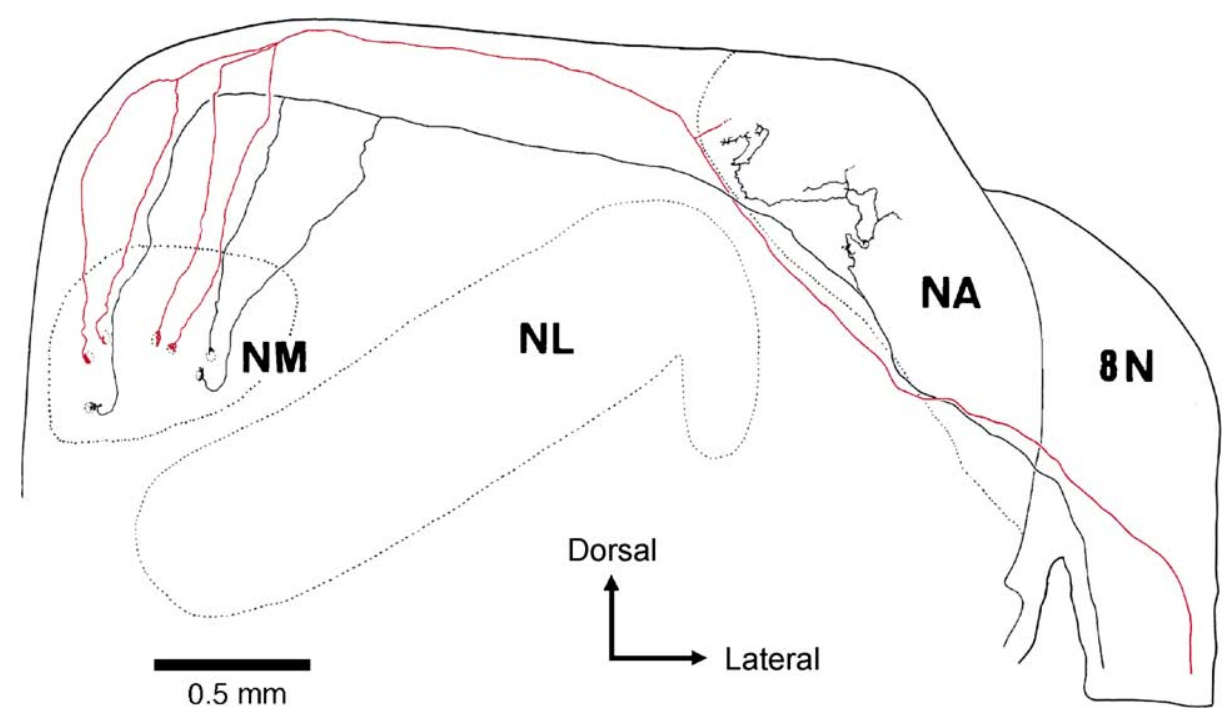

Fig. 1. Projections of the chick auditory nerve to cochlear nucleus magnocellularis (NM) and cochlear nucleus angularis (NA) as viewed in the frontal plane. Two fibers are shown but only a single arbor into NA. Upon entering the brain, the main branch gives rise to a lateral branch to NA and a medial branch to NM. The lateral branch is thinner and terminates as bouton endings. The medial branch is thicker and gives rise to 3-4 collaterals, each tipped by an endbulb. Modified from Carr and Boudreau [29], Wiley-Liss publishers. 
(A)
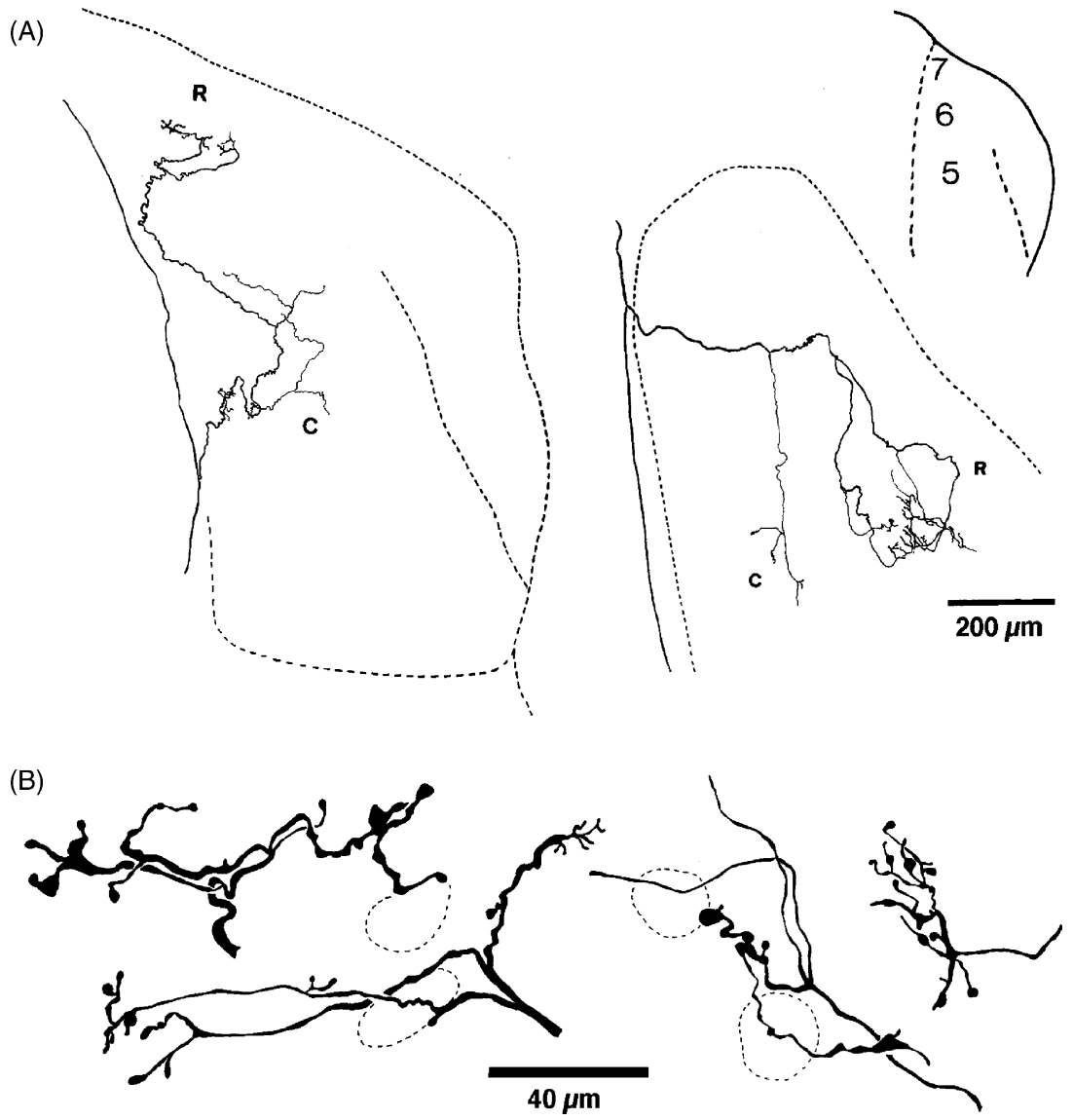

Fig. 2. Projections of the lateral branch of the chick auditory nerve to nucleus angularis (NA) as viewed in the frontal plane. (A) These fibers have CFs of $7 \mathrm{kHz}$ (left) and $5.5 \mathrm{kHz}$ (right). These drawings show the rostral (R) and caudal (C) terminal fields. The inset at the upper right illustrates the tonotopic organization of NA. (B) The collaterals illustrate the bouton endings, en passant swellings, and small complex endings. Modified from Carr and Boudreau [29], Wiley-Liss publishers.

( $\alpha$-amino-3-hydroxy-5-methyl-4-isoxazolepropionate) receptors have been identified on NA neurons dissociated from chick embryos [150]. AMPA receptors in the chick NA are highly permeable to divalent cations [228], and NA neurons in the barn owl strongly express immunoreactivity for the AMPA receptor subunits GluR4 and GluR2/3 but not for GluR1 [96]. These results are consistent with the general finding, much better characterized in NM (see below), that brainstem auditory neurons express AMPA receptors with very rapid desensitization and deactivation kinetics and high permeability to $\mathrm{Ca}^{2+}$ [139]. There is good evidence for a high density of GABAergic axon terminals in the NA in barn owl [32] and chicken [38] as well as a small number of GABA-positive neurons (barn owl, [32]; chicken, [123]). Only very rarely are glycine-immunoreactive axon terminals encountered in NA of the chick [39].

\subsection{Nucleus magnocellularis (NM)}

\subsubsection{Innervation}

The medial branch of the cochlear nerve continues dorsally after emitting the lateral branch that innervates NA and arches across the brain stem to innervate the NM (Fig. 1).
This relatively large region through which AN fibers pass does not have a counterpart in the mammalian brain stem. It does, however, represent a potentially interesting site for making lesions that would selectively denervate NM for behavioral studies. As the fiber courses caudal-to-rostral above the NM, it gives off several branches (three to six in the barn owl, [31]). Each collateral branch descends ventrally to form a single endbulb on a NM cell body and the distribution of the endings corresponds to the tonotopic organization of the nucleus $[165,201]$. Endbulbs are a large calyx-like axosomatic ending formed by auditory nerve fibers in a wide variety of terrestrial vertebrates, including turtles [24], lizards [199], birds [31,78,140], mice [22,102], guinea pigs [208], cats $[103,170,175]$, and humans [1]. The endbulb arises from the main axon as several gnarled branches that arborize repeatedly to enclose the postsynaptic cell in a nest of en passant swellings and terminal boutons (Fig. 3).

Anatomical [29,138,142] and electrophysiological evidence [76] suggests that each NM neuron, on average, receives two endbulbs, with a range of 1-3 in mature animals. There are differences in ending characteristics for fibers with low CFs $(0.25-0.64 \mathrm{kHz})$ compared to endings from higher $\mathrm{CF}$ fibers. Cochlear nerve endings in the 


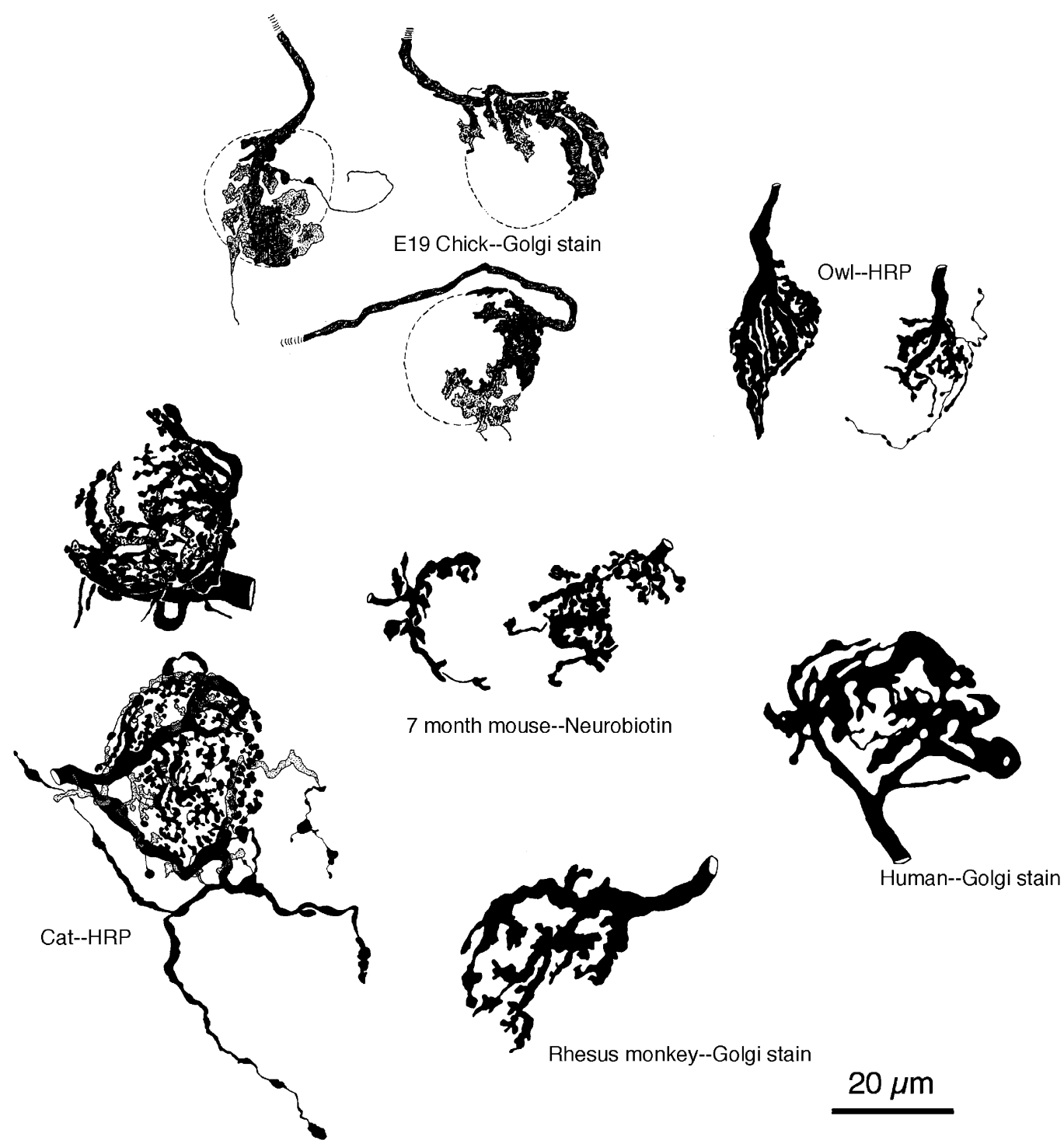

Fig. 3. Comparative view of endbulbs from birds and mammals, including staining method. These large axosomatic endings are formed by auditory nerve fibers across a wide variety of animals. Their size and numerous synaptic release sites imply a powerful influence upon the postsynaptic neuron, and their function has been inferred to mediate precise temporal processing. The evolutionary advantages conferred by accurate timing information are embedded in sound localization acuity and auditory discrimination skills. Chick endbulbs are from Jhaveri and Morest [77,78], Plenum Press; owl endbulbs are from Carr and Boudreau [31], Wiley-Liss publishers; mouse endbulbs are from Limb and Ryugo [102], Springer publishers; cat endbulbs are from Ryugo et al. [174], Wiley-Liss publishers, and Sento and Ryugo [185], Liss publishers; monkey endbulb is from Ryugo, unpublished data; human endbulb is from Adams [1], American Medical Association.

lowest-frequency ventrolateral portion of the barn owl NM do not form endbulbs but, rather, branch multiple times to terminate as en passant swellings, terminal boutons, and lobulated endings [90]. This contrasts with the situation in mammals (see below) in which even the lowest-CF bushy cells in the AVCN receive endbulbs and with the high-CF fibers in barn owl, which do not branch but terminate as single endbulbs on NM neurons. Because it is clear that the low-frequency portions of NM do not, as previously thought, receive inputs from the nonauditory macula lagena [80], it has been of interest to consider the functional differences in neurotransmission conferred by the different ending morphologies. NM neurons in both low- and high-frequency regions phase-lock well [90] so that if, as is commonly thought [207], endbulbs are specializations for preserving timing of auditory signals, they are only needed for high-frequency signaling in birds. A detailed comparison of synaptic transmission at low-frequency synapses in birds (no endbulbs) and mammals (endbulbs) has the potential to reveal functional specializations provided by the endbulb.

\subsubsection{Cellular organization}

The avian NM contains a population of neurons called bushy cells $[30,31,78,187]$. These cells exhibit large round-to-oval cell bodies with many short somatic spines; in hatchling chickens, $40 \%$ of NM neurons have a single 
rudimentary dendrite [40]. In response to $\mathrm{CF}$ tones, NM neurons show "primary-like" poststimulus time histograms (PSTHs) and have irregular spike discharge patterns and high rates of spontaneous activity [92,181,197,214]. Importantly, however, these neurons discharge in a phase-locked manner to the auditory stimulus, preserving time cues necessary for azimuthal location of the sound source [113].

\subsubsection{Fine structure}

The ultrastructure of endbulbs in NM has been studied in the chick [77,138,141,142] and the barn owl [29]. The endbulbs appear most often as large elongated profiles that contain multiple sites of synaptic specialization formed directly on the cell body or on the sides of the many somatic spines; in the barn owl, $64 \%$ of the synapses are on spines. Endbulbs exhibit characteristic assemblies of organelles, including large numbers of small mitochondria, clathrin-coated endocytic vesicles and membrane-bound cisterns [29]. Except at multiple punctate synaptic contacts (which occupy about $15 \%$ of the membrane apposition between endbulb and NM cell), the endbulb is separated from the postsynaptic cell by spaces of variable width. The synaptic specializations are characterized by large $(45 \mathrm{~nm})$ clear round synaptic vesicles and asymmetric membrane
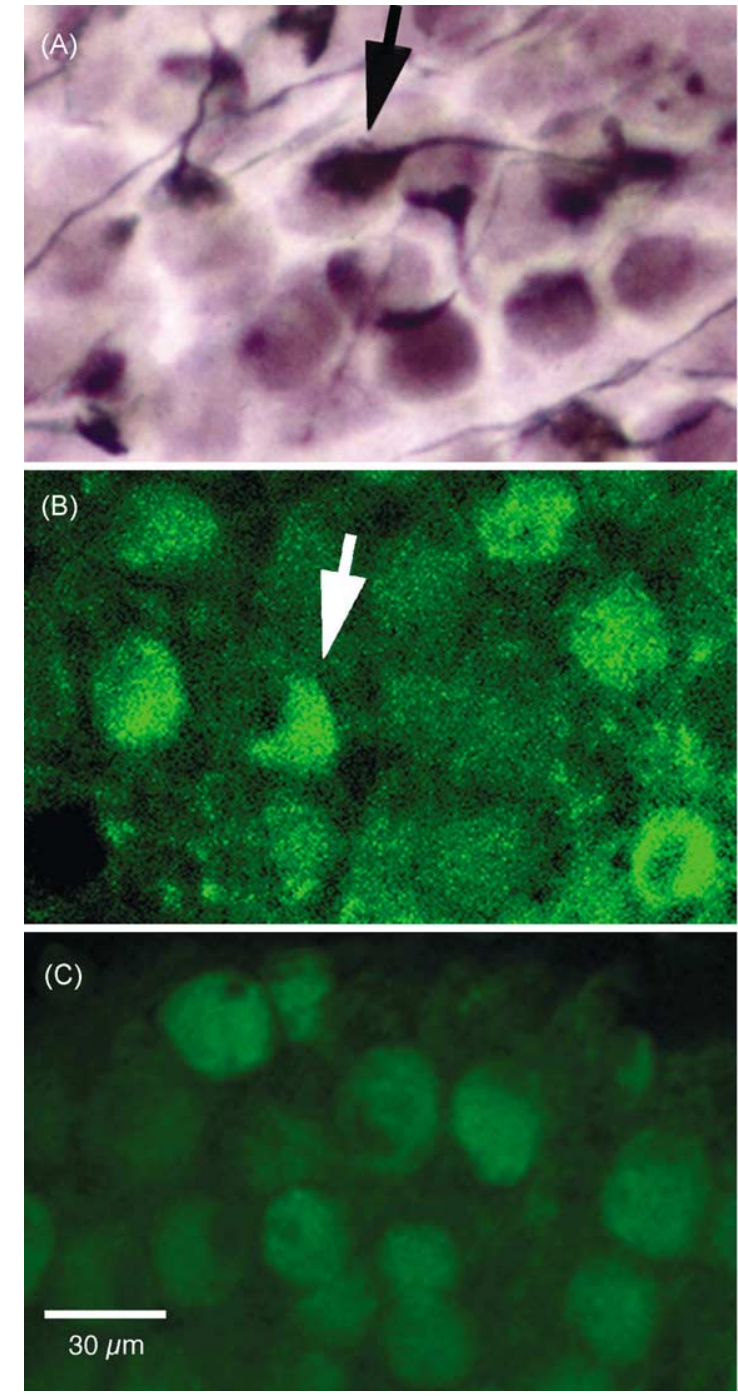

(D)
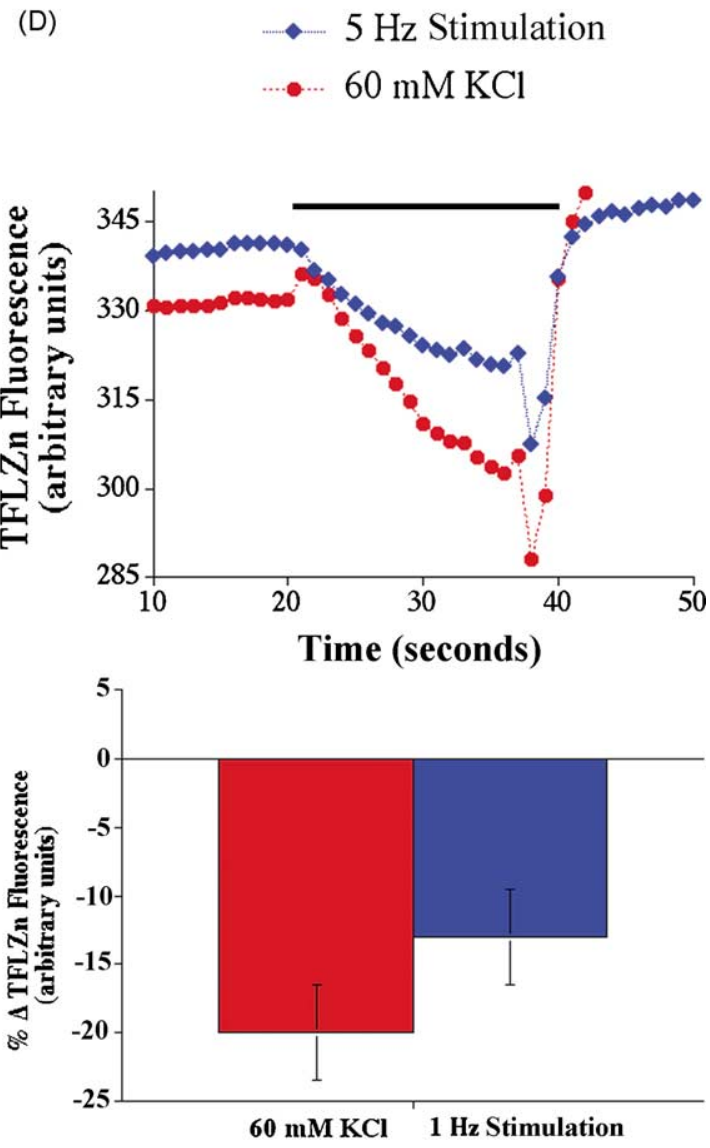

Fig. 4. TFLZn [N-(6-methoxy-8-quinolyl)-p-carboxybenzoyl-sulphonamide] labels endbulbs in chick nucleus magnocellularis (NM) at embryonic day (E)18 and indicates zinc release from the endbulb during depolarization. (A) Endbulbs labeled with HRP (arrow) and counterstained with thionin. (B) Endbulbs labeled with TFLZn (white arrow), a fluorescent dye specific for vesicularized zinc. Note the same morphology as those endbulbs labeled in (A). (C) NM labeled with TFLZn $72 \mathrm{~h}$ after cochlea ablation, a time at which the cochlear nerve and its endbulbs have degenerated. Note the distinctly different staining pattern from that shown in (B). (D) TFLZn fluorescence decreases in response to cochlear nerve stimulation and $\mathrm{KCl}$ depolarization. Top panel shows average TFLZn fluorescence from eight neurons in a single slice that received $20 \mathrm{~s}$ of cochlear nerve stimulation (blue diamonds) and $20 \mathrm{~s}$ of depolarization (both indicated by a horizontal bar) with $60 \mathrm{mM} \mathrm{KCl}$ (red circles). For comparison, both traces have been normalized to the same time abscissa. Lower panel shows the average decrease of TFLZn fluorescence in response to cochlear nerve stimulation $(n=6, P=0.013)$ and depolarization with $60 \mathrm{nM} \mathrm{KCl}(n=8, P=0.0007)$. The graphs demonstrate zinc depletion (or release) from presynaptic endbulbs following activation. Adapted from Zirpel and Parks [232], Springer publishers. 
specializations. The 34-nm thick postsynaptic densities resemble the simple densities classified as type II or III [62]. Morphometric analyses of endbulbs reveal that these endings occupy about $45 \%$ of the NM somatic surface in late-stage chick embryos [142] and about $60 \%$ in adult birds [138].

\subsection{Transmitters and receptors}

\subsubsection{Ionotropic glutamate receptors}

An excitatory amino acid, most likely glutamate, is the neurotransmitter released from cochlear nerve endings in birds and this substance interacts with several classes of glutamate receptor. The glutamate receptors of the chick NM have been studied extensively and it is clear that the ionotropic AMPA receptors mediate most rapid transmission at the cochlear nerve-NM synapse [75,149,227]. Although there is evidence for some NMDA ( $N$-methyl-D-aspartate) receptor-mediated excitatory transmission at the cochlear nerve-NM synapse [225], particularly at early stages of development [226], it is very small relative to the AMPA receptor-mediated component. Despite efforts to detect functional kainate receptors at this synapse using highly selective drugs, no positive evidence for them has been found. Thus, research has focused on understanding the functional and structural specializations of AMPA receptors that are key features in the distinctive response properties of bushy cells in the NM and AVCN.

The AMPA receptors of brainstem auditory neurons show specializations that allow them to produce the large rapid excitatory postsynaptic currents necessary for rapid and precise representation of auditory stimuli (reviewed by [207] and [139]). Much of the data supporting the existence of "auditory" AMPA receptors has come from studies of the chick NM. Functional studies have shown that AMPA receptors of NM neurons have the fastest known desensitization and deactivation kinetics [150] and that they have inwardly rectifying current-voltage relationships, high permeability to divalent cations and high sensitivity to block by polyamine toxins $[136,153,228]$. Structural studies of these receptors have shown that they consist largely of GluR3 and GluR4 subunits expressed in the rapidly desensitizing flop splice variants and that expression of GluR2, which normally prevents permeability to divalent cations, is almost completely abolished during development by both transcriptional and posttranscriptional controls $[96,153,196]$.

\subsubsection{Metabotropic glutamate receptors}

In addition to its effects on receptors coupled directly to ion channels (the ionotropic AMPA, NMDA, and kainate receptors discussed above), neurotransmitter released from cochlear nerve terminals also activates receptors that are coupled to G-proteins, the metabotropic glutamate receptors (mGluRs). These receptors are classified into three groups (I, II, and III) based on the nature of their intracellular effector mechanisms [41]. Activity-dependent activation of Group I
mGluRs (which includes two related proteins, mGluRs 1 and 5) releases $\mathrm{Ca}^{2+}$ from intracellular stores in chick NM neurons by activating phospholipase $\mathrm{C}$, which generates $\mathrm{IP}_{3}$ [231]. This mGluR-mediated effect on calcium homeostasis develops in parallel with synaptic activity in NM [229] and has been shown to be necessary for the survival of many NM neurons [230,231]. It has recently been found that zinc is localized in chick cochlear nerve endbulbs (Fig. 4) and released during nerve stimulation [232]. This zinc inhibits mGluR5 receptors on NM neurons and contributes to the complex, activity-dependent mGluR-mediated calcium homeostasis that is essential for NM neuron maintenance and survival. Since zinc has also been shown to modulate GABA receptors, NMDA receptors, and glutamate transporters and is present in the mammalian cochlear nucleus, synaptically released zinc from the cochlear nerve may play an important role in the overall functioning of cochlear nucleus neurons in birds and mammals [232].

\section{Mammals}

Differences between the organization of the avian basilar papilla and the mammalian cochlea are further emphasized by features of the spiral ganglion neurons, primary neurons in mammals, which convey the output of the receptors as input to the brain. There are normally two separate populations of ganglion cell types in adult mammals on the basis of somatic size and staining characteristics [85,124,193,194]. There are large, bipolar, type I cells and small, pseudomonopolar type II cells (Fig. 5A). These two ganglion cell populations have been shown to maintain separate innervation of the two types of hair cell receptors [13,21,60,87]. The somata of type I ganglion cells are relatively large, and are rich in ribosomes and cytoplasmic organelles (Fig. 5B). They constitute $90-95 \%$ of the population, innervate inner hair cells, and have myelinated axons. In contrast, the somata of type II cells are relatively small and filamentous. Type II ganglion cells constitute the remaining $5-10 \%$ of the population, innervate outer hair cells, and are unmyelinated.

The variation in organelle composition can be exploited to specifically stain the type II cell population $[12,14,67]$ in order to study the differential maturation of ganglion cells (humans, [45]; mice, [159]) or the selective effects of ototoxic agents on the spiral ganglion [42]. For example, type II spiral ganglion neurons are selectively stained by antibodies directed against the phosphorylated form of the $200 \mathrm{kDa}$ neurofilament subunit $[12,14]$, peripherin, an intermediate neurofilament [66], or calbindin [189]. These studies have readily confirmed that type II neurons represent only $5-10 \%$ of the population and are uniformly distributed along Rosenthal's canal. That is, there is no frequency specialization for the distribution of type II cell bodies.

There is a relatively wide range in ganglion cell counts across different mammalian species. For example, there are 


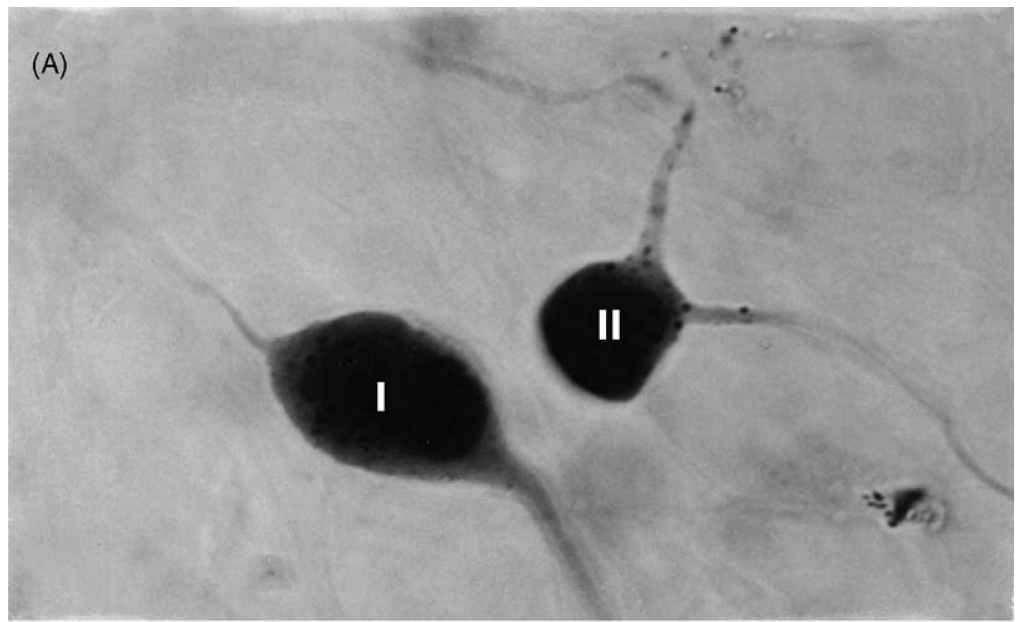

(B)

(C)
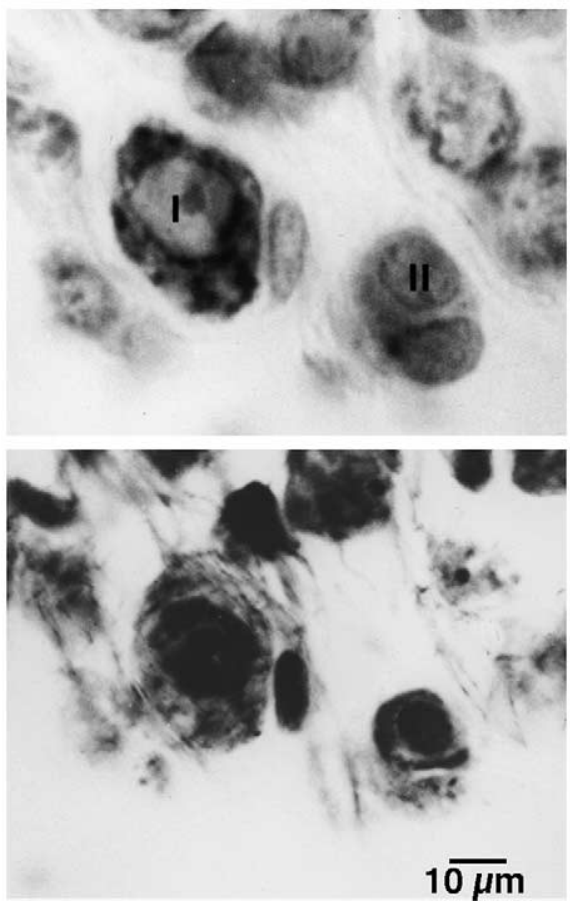

Fig. 5. Light microscopic appearance of mammalian spiral ganglion cells. (A) HRP labelled cells that are representative of the two types. Type I ganglion cells represent $90-95 \%$ of the population, have larger cell bodies, and are characterized by a thin peripheral process and thicker central process. These cells innervate a single inner hair cell. Type II ganglion cells represent $5-10 \%$ of the population, have smaller cell bodies, and innervate multiple outer hair cells. Adapted from Kiang et al. [87], AAAS publishers. (B) The cytoplasm of type I cells is "blotchy" when stained with basophilic dyes, revealing ribosomes, Nissl bodies, and a pale nucleus. In contrast, the type II cells are pale, with few ribosomes in their somata but darker staining chromatin in the nuclei. (C) The cytoplasm of type I cells is pale when stained for neurofilaments (protargol) but dark in type II cells. The data reveal a ribosome-rich cell body for type I cells and a filament-rich cell body for type II cells. Adapted from Berglund and Ryugo [12], Elsevier publishers.

50,000 in cats [55], 31,400 in human [152], 31,250 in rhesus monkeys [55], 31,240 in squirrel monkeys [3], 15,800 in rat [83], and 12,250 in mice [48]. The proportion of 90-95\% type I cells and 5-10\% type II cells, however, is fairly constant.

\subsection{Cochleotopy}

When auditory nerve fibers are anterogradely labeled with horseradish peroxidase following discrete injections into the nerve or ganglion, bundles of thick and thin fibers are observed in the nerve root and cochlear nucleus (Fig. 6). These fibers can be followed back along the auditory nerve into the cochlea where the thick fibers $(2-4 \mu \mathrm{m}$ in thickness) are found to arise from type I spiral ganglion neurons and the thin fibers $(0.5 \mu \mathrm{m}$ in thickness) are shown to arise from type II spiral ganglion neurons [22,23,87]. These fibers can also be followed centrally into the cochlear nucleus, as was described long ago using the Golgi staining method $[103,151]$. The thick fibers are myelinated, whereas the thin 


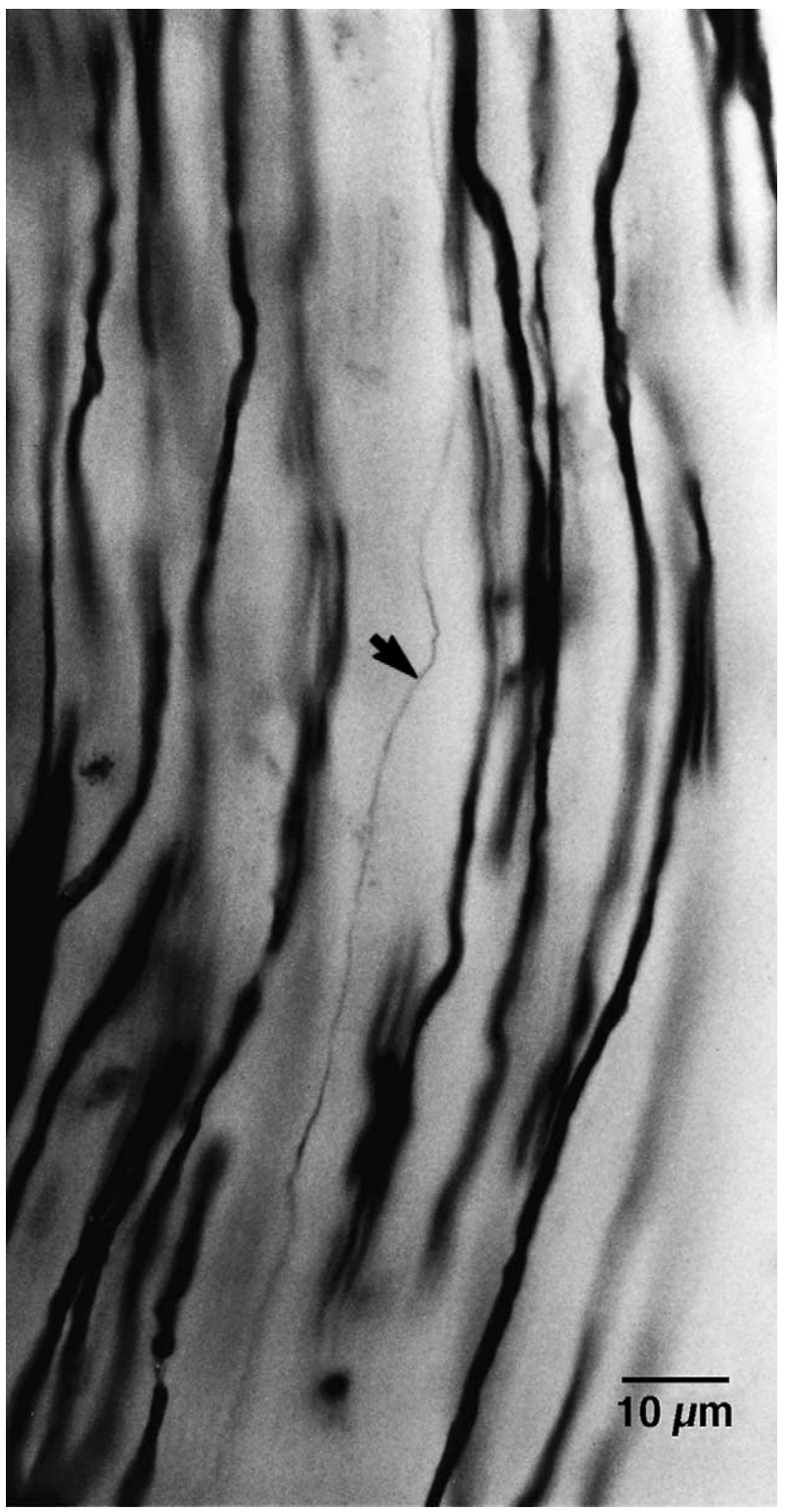

Fig. 6. Photomicrograph of HRP-labeled auditory nerve fibers in the cat. Most of the fibers are 2-4 $\mu \mathrm{m}$ thick and represent the central axons of type I spiral ganglion cells. An occasional fiber is thin (arrow) and arises from the type II spiral ganglion cell. The thick fibers are myelinated, whereas the thin ones are not.

fibers are unmyelinated [71,169]. The thick fibers give rise to one or several large endings called endbulbs, whereas both fiber types give rise to short collaterals with many en passant swellings and terminal boutons (Fig. 7). The type I terminals stay within the magnocellular part of the cochlear nucleus, where ascending projections of the central auditory pathways are initiated. The type II terminals overlap with the terminal zone of the type I fibers in the magnocellular core but also send collaterals and terminals into the surrounding microneuronal shell that is comprised of the granule cell domain (GCD) and underlying small cell cap.
These fibers, whether myelinated or unmyelinated, exhibit a cochleotopic projection pattern (Fig. 8). From a discrete location along the cochlear duct, their bifurcations and trajectories within the nucleus are closely intertwined, and their distribution is systematically related to their origin $[11,21,22,118]$. Both types I and II fibers send one branch into the anteroventral cochlear nucleus (AVCN), and a second branch through the posteroventral cochlear nucleus $(\mathrm{PVCN})$ and into the dorsal cochlear nucleus (DCN). The projection through the magnocellular $\mathrm{CN}$ by types I and II fibers is cochleotopic, whereas the projection into the GCD by type II fibers is not $[11,118]$.

\section{Physiological response properties}

In mammals, individual type I auditory nerve fibers may be defined by three fundamental properties: [1] frequency selectivity, [2] response threshold, and [3] spontaneous discharge rate. Frequency selectivity refers to the fiber's tendency to be most sensitive to a single frequency as defined by a "threshold-tuning curve" $[49,88]$. The fiber will respond to any combination of level and frequency that falls within its curve. The tip of the curve indicates the frequency to which it is most sensitive, called the $\mathrm{CF}$, and it is also the fiber's threshold in dB SPL to that frequency. The CF reflects the longitudinal location of fiber termination along the organ of Corti [98].

\subsection{Tonotopy}

The most direct method demonstrating a cochleotopic and tonotopic projection resulted from the application of single fiber recording and staining methods $[168,171,208]$. In this way, the very cell that is physiologically characterized is also the one that is stained. These data reveal that all single-unit activity recorded from the auditory nerve has been derived from the myelinated fibers of type I ganglion cells, and that essentially nothing is known about the response properties of the type II ganglion cells [98,99]. Ganglion cells innervating hair cell receptors in the apical region of the cochlea distribute their axon and terminals in a ventral zone of the nucleus, whereas ganglion cells innervating progressively more basal hair cells project to progressively more dorsal zones of the nucleus (Fig. 9, top). It should also be noted that $85 \%$ of individually labeled fibers project throughout the ventral and dorsal cochlear nucleus; $15 \%$ innervate only the ventral cochlear nucleus [51]. The significance of these projection differences is not known, nor is there any information regarding possible differences in cell body morphology, distribution, or hair cell innervation.

Upon passing the Schwann-glia border (marking entrance into the central nervous system), individual auditory nerve fibers penetrate a variable distance into the nucleus, depending upon fiber $\mathrm{CF}$, and bifurcate into an ascending branch and a descending branch. The ascending branch has a 


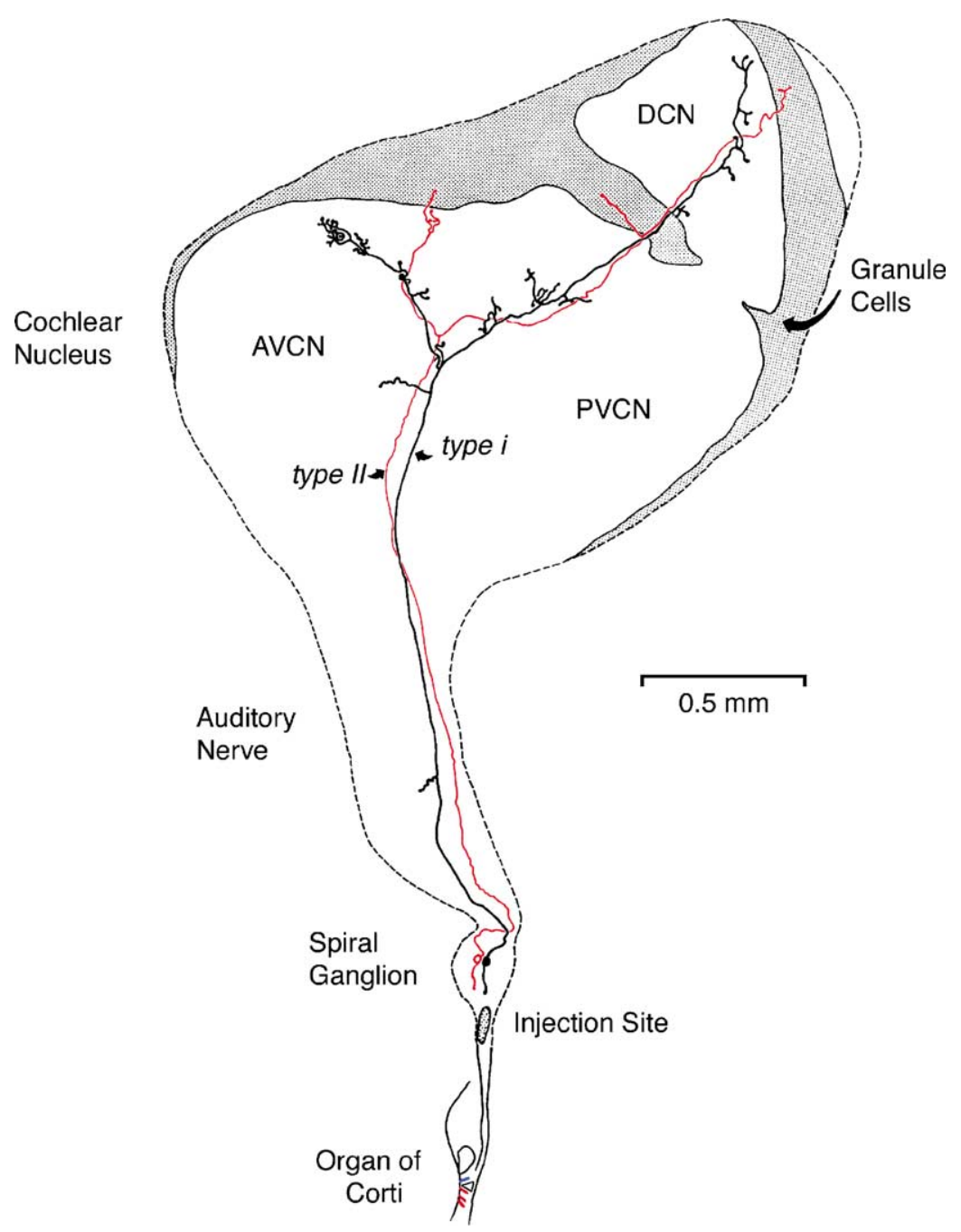

Fig. 7. Drawing tube reconstruction of the central axons of a type I spiral ganglion cell (thick black line) and a type II ganglion cell (thin red line). These axons and their endings were reconstructed through serial sections of the auditory nerve and cochlear nucleus from their origins in the spiral ganglion. Although the trajectories of these axons are similar, the terminations of the type II neurons are distributed in the granule cell domain, consistently separated from those of type I neurons. Abbreviations: AVCN, anteroventral cochlear nucleus; DCN, dorsal cochlear nucleus; PVCN, posteroventral cochlear nucleus. Adapted from Brown et al. [22], Wiley-Liss publishers.

relatively straight trajectory into the AVCN and terminates as a large, axosomatic ending called the endbulb of Held. The descending branch likewise has a straight trajectory through the PVCN before entering the DCN. Along the way, these main branches give rise to short collaterals. The collaterals ramify further and exhibit en passant swellings and terminal boutons. Fibers of similar CFs disperse to form a 3-dimensional sheet running through the nucleus, and stacks of these sheets represent the isofrequency contours of the nucleus (Fig. 9, bottom). The sheets have a horizontal orientation within the ventral cochlear nucleus but twist caudally to form parasagittal sheets in the DCN. These projections underlie the tonotopic organization of the resident neurons of the cochlear nucleus $[19,160,191]$. The data also indicate that although both divisions of the cochlear nucleus are tonotopically organized, the DCN has more tissue devoted to high frequencies compared to the
VCN. It has previously been speculated that this specialization might be related to the detection of "spectral notches" in head-transfer functions for localizing sounds in space [191].

\subsection{Spontaneous discharge rate (SR)}

Unlike birds, SR in the mammalian auditory nerve forms a bimodal distribution where $30-40 \%$ of the fibers have SR $<10$ spikes/s and $60-70 \%$ have SR $>30$ spikes/s. Threshold is correlated to the amount of spontaneous spike activity (SR) that occurs in the absence of experimenter-controlled stimulation. Low-SR fibers have relatively high thresholds, whereas high-SR fibers have low thresholds. Across the audible frequency range, fibers of similar CFs can vary in SR from near 0 to $>100$ spikes/s. The bimodal SR distribution is present across the entire audible frequency range for the 

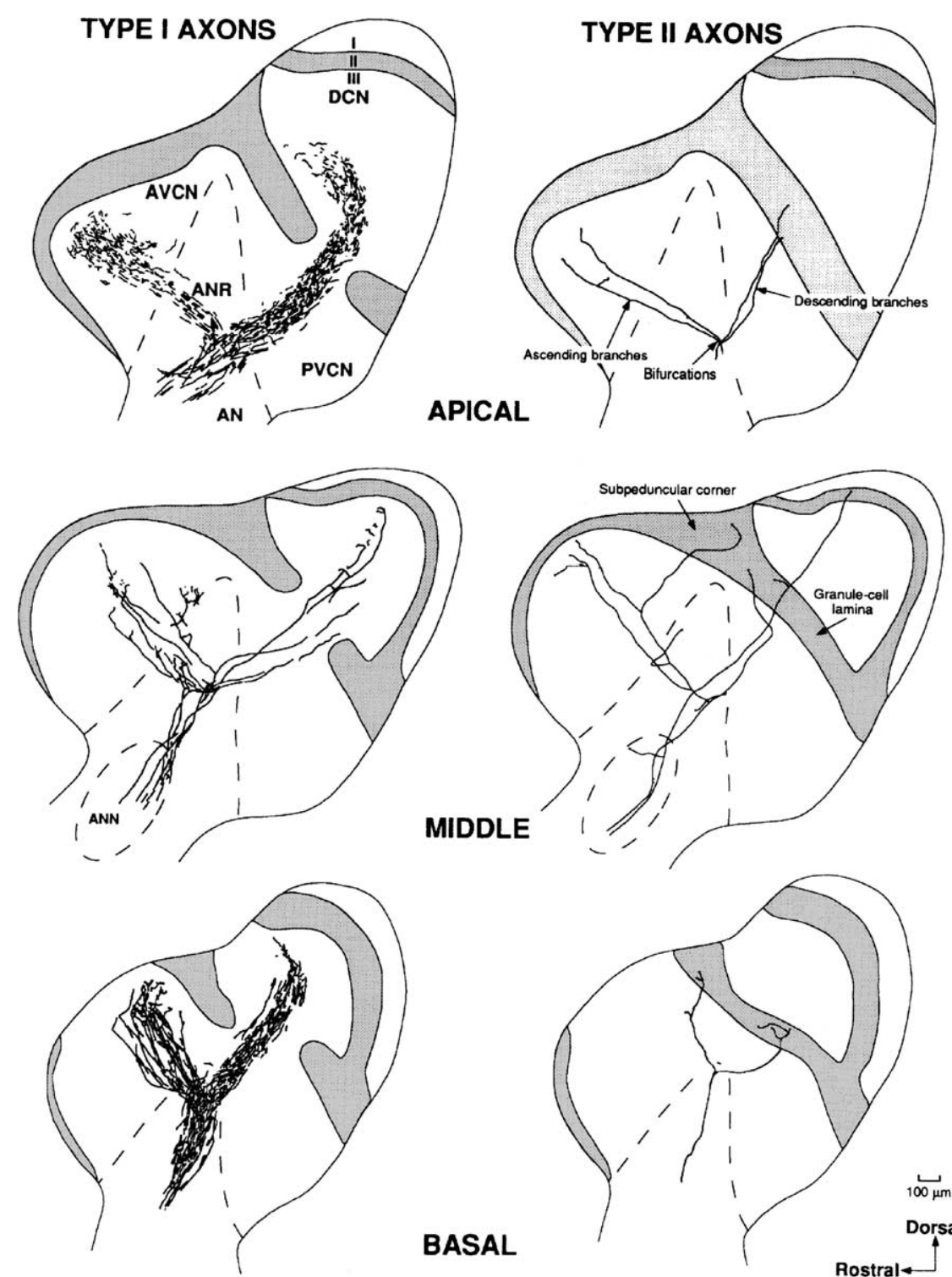

BASAL

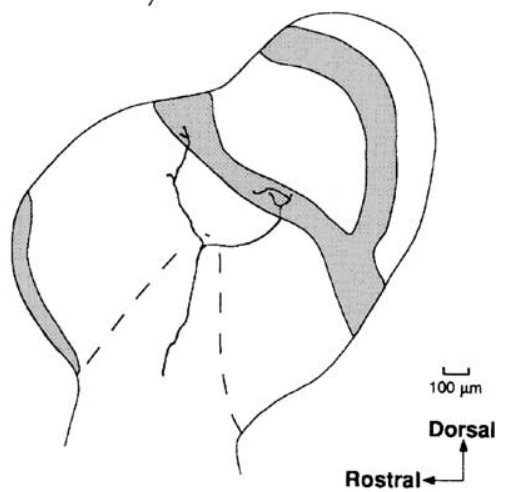

Fig. 8. Drawing tube reconstructions of the cochlear nuclei of three separate mice, as viewed in sections collected parallel to the lateral surface of the nucleus. The labeled fibers are a result of HRP injections into apical (top panels), middle (center panels), and basal (bottom panels) turns of the cochlea. The left column illustrates the distribution of type I auditory nerve fibers, whereas the right column shows type II fibers. The drawings also illustrate how type I fibers enter the DCN by passing medial to the granule cell lamina. In contrast, type II fibers travel directly into the granule cell lamina without continuing on to the DCN. Abbreviations: AN, auditory nerve; ANN, nucleus of the auditory nerve; ANR, auditory nerve root; AVCN, anteroventral cochlear nucleus; DCN, dorsal cochlear nucleus; I, II, III, layers of the DCN; PVCN, posteroventral cochlear nucleus. Adapted from Berglund and Brown [11], Elsevier publishers.

animal (e.g. cat [50,88,97]; gerbil [183]; guinea pig [208]), and implies a general organizational principle for the mammalian auditory nerve. Fibers of the different SR groupings exhibit distinct physiologic features, especially in terms of their contribution to the dynamic range of hearing $[50,59,179]$ and representation of speech sounds $[110,180,212,223]$. The collective evidence suggests that different SR groupings of auditory nerve fibers serve separate roles in acoustic information processing. It might be that the high-SR fibers with their low thresholds prefer to function in quiet, whereas low-SR fibers with their high thresholds operate better in loud and noisy environments.

\section{Structure-function correlates}

\subsection{SR and peripheral correlates}

Morphologic specializations have been found in the innervation pattern of inner hair cells with respect to SR fiber groupings. High-SR fibers ( $>18$ spikes/s) have thick peripheral processes that tend to contact the "pillar" side of the inner hair cell, whereas low-SR fibers $(<18$ spikes/s) have thin peripheral processes that tend to contact the modiolar side of the hair cell $[98,111]$. Furthermore, there is SR segregation within the spiral ganglion. Low-SR neurons 


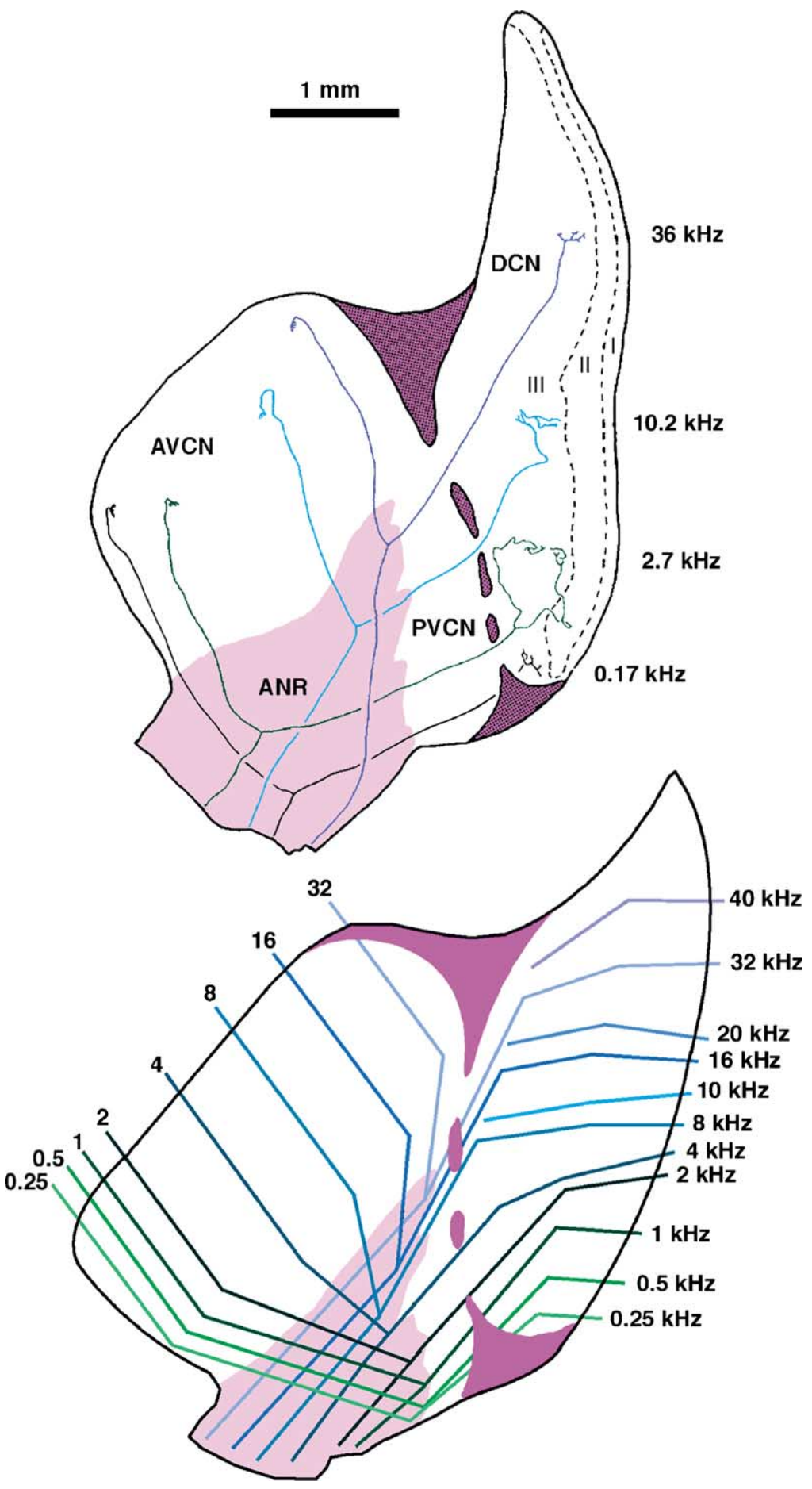

Fig. 9. (Top) Cochleotopic projection of type I auditory nerve fibers into the cochlear nucleus. A systematic projection was noted by the classic Golgi anatomists [104,151], but intracellular recording and labeling methods directly established the tonotopic organization [171]. (Bottom) This projection was revealed to reflect the tonotopic organization of cochlear nucleus cells $[19,171]$. One observation from these data is that the DCN has more tissue devoted to high frequency information processing than that of the VCN. Abbreviations: ANR, auditory nerve root; AVCN, anteroventral cochlear nucleus; DCN, dorsal cochlear nucleus; PVCN, posteroventral cochlear nucleus.

tend to be distributed on the side of the scala vestibuli, whereas high-SR fibers can be found throughout the ganglion $[82,100]$. These peripheral differences are maintained by the pattern of central projections, and embedded within the tonotopic organization.

\subsection{SR and central correlates}

There are morphologic correlates that correspond to groupings of fibers with respect to SR. Compared to fibers of high SR ( $>18$ spikes/s), fibers of low SR ( $<18$ spikes/s) 
(A)
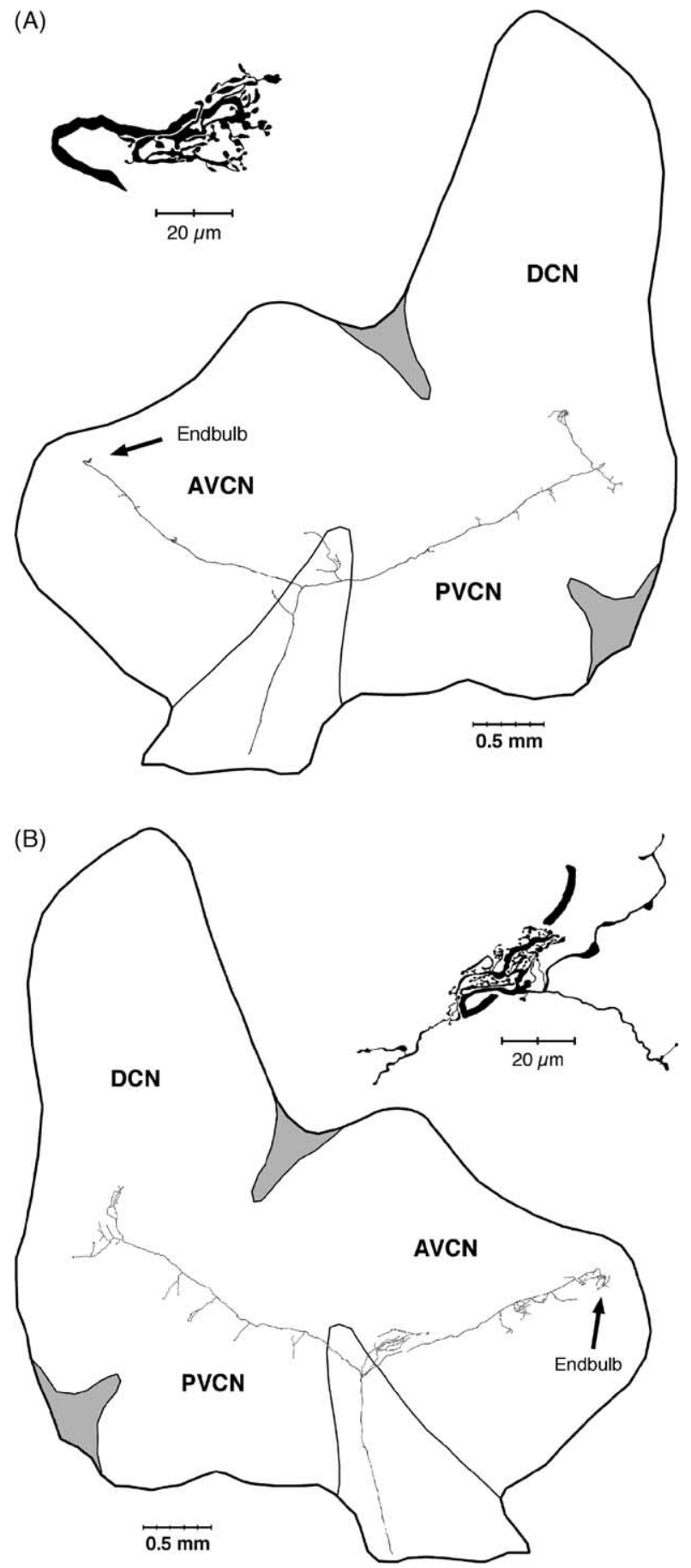

Fig. 10. Light microscopic reconstructions of intracellularly characterized and stained type I auditory nerve fibers with terminal endbulbs. The morphology of each fiber is representative of the class of high-SR (A) and low-SR (B) groupings. (A) This high-SR fiber $(\mathrm{CF}=4.7 \mathrm{kHz}$, $\mathrm{SR}=32$ spikes/s) projects topographically through all three divisions of the cochlear nucleus and exhibits relatively simple branching. (B) The low-SR fiber $(\mathrm{CF}=4.5 \mathrm{kHz}, \mathrm{SR}=0.3$ spikes/s) also projects topographically through the cochlear nucleus but displays greater axonal arborizations along its ascending branch within the AVCN. Note especially, the collaterals arising at the bifurcation and in the vicinity of the endulb. These collaterals distinguish low-SR fibers from high SR fibers. They ramify within the small cell cap, a region of small cells that lie beneath the granule cell domain. Light microscopic, drawing tube reconstruction exhibit different innervation characteristics with the IHCs [99,111], give rise to greater collateral branching in the AVCN [51], emit collaterals that preferentially innervate the small cell cap [100,177], and manifest striking specializations in the large axosomatic endings, the endbulbs of Held [185] and their synapses [178].

The typical high-SR fiber traverses the nucleus and gives rise to short collaterals that branch a few times before terminating (Fig. 10A). There was a suggestion that projections of the different SR groups might be segregated along a medial-lateral axis within the core of the AVCN [94] but single-unit labeling studies do not unambiguously support or refute this proposal $[51,82,100,208]$. There are usually one or two terminal endbulbs at the anterior tip of the ascending branch, and the remaining terminals appear as en passant swellings or terminal boutons. It is presumed that these swellings are sites of synaptic interactions with other neuronal elements in the cochlear nucleus. Approximately 95\% of all terminal endings were small and round, definable as "bouton-like" [163]. The remaining endings were modified endbulbs that tended to contact the somata of globular bushy cells and large endbulbs of Held that contacted the somata of spherical bushy cells. In contrast to birds, low-frequency myelinated auditory nerve fibers in mammals give rise to endbulbs. Furthermore, the endbulbs of low-frequency fibers tend to be the largest of the entire population of fibers.

There is a clear SR-related difference in axonal branching and the number of endings. Low-SR fibers give rise to greater collateral branching in the AVCN compared to that of high-SR fibers [51,100,101,208]. In cats, the ascending branch of low-SR fibers give rise to longer collaterals, twice as many branches (there are approximately 50 branches per low-SR fiber compared to 25 per high-SR fiber), and twice as many bouton endings (Fig. 10B). These endings, while more numerous, are also smaller compared to those of high-SR fibers [163]. The greater total collateral length is illustrated by low-SR fibers that have an average of $5 \mathrm{~mm}$ of collaterals per ascending branch compared to $2.8 \mathrm{~mm}$ of collaterals per high-SR fiber [51]. The inference from these observations is that low-SR fibers contact more neurons distributed over a wider region of the cochlear nucleus than do high-SR fibers. If the perception of loudness is proportional to the number of active neurons [195], then this branching differential may provide the substrate. The activation of high-threshold, low-SR fibers by loud sounds would not only increase the pool of active auditory nerve fibers but also produce a spread of activity throughout the AVCN. This recruitment would

of endbulbs are presented in higher magnification. These two endbulbs are representative of their respective spontaneous rate grouping. The endbulb from the high-SR fiber (A) is less highly branched and has larger en passant swellings and terminals. In contrast, the endbulb from the low-SR fiber (B) is more elaborately branched and has more but smaller components. These differences are reliably quantified using fractal analysis. 
be useful because the discharge rate of high-SR fibers is already saturated at moderate sound levels.

There is no systematic difference in the average number of terminals generated by the descending branch with respect to fiber SR. Low-SR fibers do, however, have a wider distribution across the frequency axis in the DCN as compared to high-SR fibers [171]. The endings lie within the deep layers of the DCN, below the pyramidal cell layer, and terminate primarily within the neuropil. The average terminal field width for low-SR fibers is $230.5 \pm 73 \mu \mathrm{m}$, whereas that for high-SR fibers is $87.2 \pm 41 \mu \mathrm{m}$. The significance of terminal arborization differences between high- and low-SR fibers might be involved in details of isofrequency laminae. The relatively short and narrow arborization of high-SR, low-threshold fibers could occupy the center of the lamina and endow those neurons with lower thresholds and sharper tuning. In contrast, the longer and broader terminal field of low-SR fibers could preferentially innervate the "edges" of the lamina. This kind of organization might establish a functional segregation of units having distinct physiological features within an isofrequency lamina, as has been proposed in the inferior colliculus [161] and auditory cortex [184,186].

\subsection{Endbulbs of Held}

Analysis of endbulbs of Held provided some insights into their role in hearing. Endbulbs are among the largest synaptic endings in the brain, emphasizing their significance if only by size. First, there is a strong influence of SR on ending morphology (Figs. 10A and B). Endbulbs having high SR (>18 spikes/s) appear stouter, with thicker but fewer branches and larger swellings. In contrast, endbulbs with low SR ( $<18$ spikes/s) exhibit a more elaborate arborization and are composed of smaller and more numerous swellings. This difference can be determined using form factor or fractal analysis, methods that quantify the shape of complex structures [102,105,172,185]. Quantitatively, these data demonstrated that endbulbs of low-SR fibers were more complex in structure compared to those of high-SR fibers.

Using quantitative measures of endbulb complexity, HRP-labeled pairs of endbulbs that contacted the same cell were analyzed [175]. These data revealed that pairs of endbulbs had nearly identical "form factor" values, indicating that fibers of the same SR groupings converged upon the same cell. Thus, SR segregation is maintained by the pattern of auditory nerve input to spherical busy cells of the cochlear nucleus.

There are activity-related features of synapse morphology [178]. Endbulbs of the different SR groups were examined with an electron microscope. It was observed that those of high-SR fibers contained larger mitochondria, and their postsynaptic densities were smaller $\left(0.088 \pm 0.05 \mu \mathrm{m}^{2}\right)$, had greater curvature, and were more numerous (mean of $1.720 \pm 395$ per endbulb). In contrast, endbulbs of low-SR fibers were larger $\left(0.177 \pm 0.06 \mu \mathrm{m}^{2}\right)$, had less curvature, and were less frequent (mean of $407 \pm 139$ per endbulb).
These ultrastructural differences were systematically related to fiber SR and are hypothesized to reflect specializations that optimize synaptic transmission.

There are ample reports of postsynaptic changes induced by reductions in synaptic input, whether experimentally or naturally induced (e.g. [137,148,155,206,209]). Much less information is available on changes in the presynaptic endings. Nevertheless, the observation that average levels of spike activity influence endbulb shape implies a kind of structural plasticity. It was, therefore, striking that in congenitally deaf cats, there was a profound lack of branching in the arbors of endbulbs (Fig. 11). This reduced complexity in endbulb morphology was quantified using fractal analysis [172]. Moreover, when comparing endbulb morphology of "hard-of-hearing" cats, that is, cats with $60-70 \mathrm{~dB}$ elevated thresholds, endbulb complexity was intermediate between those of normal hearing cats and completely deaf cats [174]. The implication is that neural activity exerts a strong influence on endbulb shape.

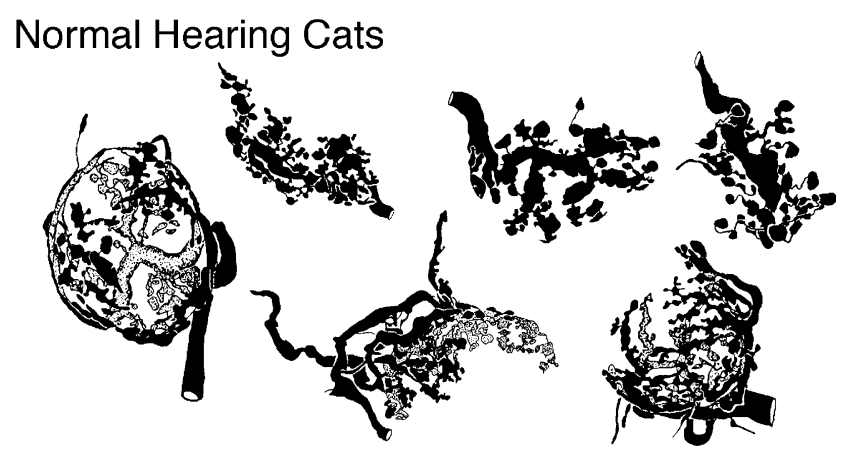

\section{Cats with Elevated Thresholds}
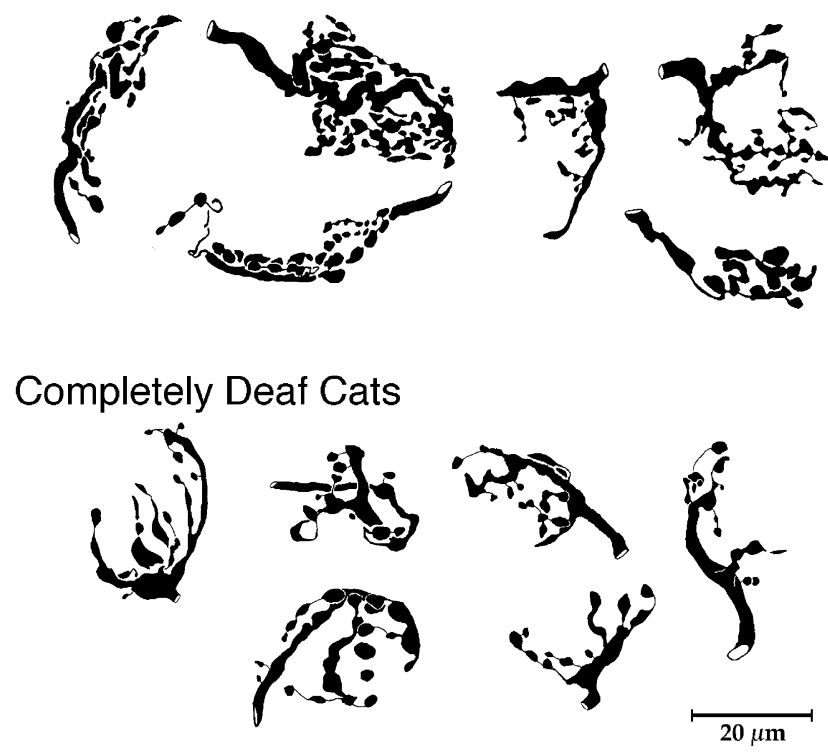

Fig. 11. Light microscopic drawing tube reconstructions of endbulbs collected from cats with normal hearing (top), cats with 60-70 dB hearing loss (middle), and completely deaf cats (bottom). Note how branching complexity is related to hearing sensitivity. Adapted from Ryugo et al. [174], Wiley-Liss publishers. 


\subsection{Modified endbulbs}

Each auditory nerve fiber gives rise to $1-2$ endbulbs of Held that contact spherical bushy cells. Smaller endbulbs, called modified endbulbs [68], are distributed in and around the region of the auditory nerve root and make axosomatic contacts with globular bushy cells [51,202-204]. Typically, 2-4 modified endbulbs are produced by a single auditory nerve fiber, and a single globular bushy cell receives up to as many as $50[103,162,190]$. The number of endbulbs and modified endbulbs does not vary with respect to fiber $\mathrm{CF}$ or fiber SR [163].

\subsection{Bouton endings}

The overwhelming majority of auditory nerve fiber endings is represented by boutons. These small endings are roundish and represent approximately $95 \%$ of the total. These occasionally contact cell bodies but usually terminate in the neuropil. Most of these boutons are distributed within the VCN, with an average of $13.4 \%$ going to the DCN.

\section{Cochlear nucleus}

The cochlear nucleus is the sole target of the axon terminals of the spiral ganglion. It is located along the dorsolateral convexity of the pontine-medullary junction, lying beneath the flocculus and paraflocculus of the cerebellum. The auditory nerve enters the cochlear nucleus from below. On the basis of cytoarchitectonic features, the cochlear nucleus can be divided into two main divisions-dorsal and ventral $[20,103,133,151]$. The DCN is characterized by a distinct layering pattern, closely resembling the cortical appearance of the cerebellum $[103,121]$. The VCN is not layered.

\subsection{Magnocellular core}

There are many organizational features that can be used to distinguish cell types within the cochlear nucleus, including but not limited to electrophysiological properties, dendritic morphology, or somatic staining characteristics (e.g. $[20,133,147,191,224])$. The different cell populations tend to be grouped together (e.g. [20,103,133]). The larger neurons reside in the magnocellular part of the nucleus and form the foundation for the ascending auditory pathways. That is, these cells send their axons to higher centers in the auditory brain stem. Most of the different neuron populations in the magnocellular core are contacted by individual auditory nerve fibers. These cells, along with the incoming auditory nerve fibers, are arranged in isofrequency contours and have identical CFs. They can, however, exhibit different thresholds and temporal patterns in their spike discharges. That is, when presented with short tone bursts at CF, the PSTH can display reliable but distinctly different patterns $[16,18,147,156]$. These PSTHs are named by their shapes, such as primary-like, chopper, onset, pauser, or build-up. Intracellular recording and staining methods have demonstrated that neurons with different firing patterns generally manifest different morphological features, including but not limited to, dendritic appearance, cell body size and shape, and axonal projections (e.g. [53,157,158,164]). Some of these differences are attributed, at least in part, to the nature of the neuron's input from the auditory nerve [86,117], but intrinsic membrane properties assume equal prominence $[5,61,107,108,129]$.

\subsection{Fine structure}

It has long been known that auditory nerve fibers gave rise to fundamentally two kinds of endings: large calycine endings and small bouton endings [70,103,151]. Because the calycine endings are among the largest in the brain, they engender considerable interest. They are typified by multiple, punctate individual synaptic contacts, associated large, round synaptic vesicles (50-60 nm in diameter), coverings by astrocytic processes, and extracellular spaces between the ending and postsynaptic cell body $[51,63,72,95,205]$. Intra-axonal labeling and degeneration studies reveal that both large and small endings share these cytologic features, emphasizing the idea that synapses of primary auditory fibers are identical $[28,51,203]$. Perhaps the most characteristic feature of primary synapses is the small, dome-shaped membrane specializations that mark the pre- and postsynaptic membrane (Fig. 12). These postsynaptic specializations flatten and hypertrophy in synapses of congenitally deaf adult cats $[154,172,174]$. How these structural alterations affect synaptic transmission remains to be determined.

\subsection{Receptors and transmitters}

The auditory system has demanding functions with respect to processing sound for localization, identification, and communication. Key to these functions is the ability to receive and transmit faithfully rapid changes in the acoustic signal. The large endbulbs of Held reflect one specialization for secure transmission $[130,146,168]$ and the amino acid glutamate is the most likely candidate that facilitates rapid transmission $[57,119,150]$. One difficulty in the identification of glutamate as the auditory nerve neurotransmitter is its ubiquitous distribution in tissue and the inability to measure its release during synaptic activity. Consequently, research efforts have been directed towards the study of pharmacologic agonists and antagonists of glutamate, the analysis of glutamate receptor subunits, and/or the role of glutamate transporters. As in birds, the bulk of available evidence implicates glutamate as the neurotransmitter for the auditory nerve. Quantitative immunogold staining methods revealed significantly greater labeling over primary endings compared to nonprimary endings (containing flat or pleomorphic vesicles) and glia [64]. Furthermore, immunogold staining was significantly lower in primary terminals that had been 

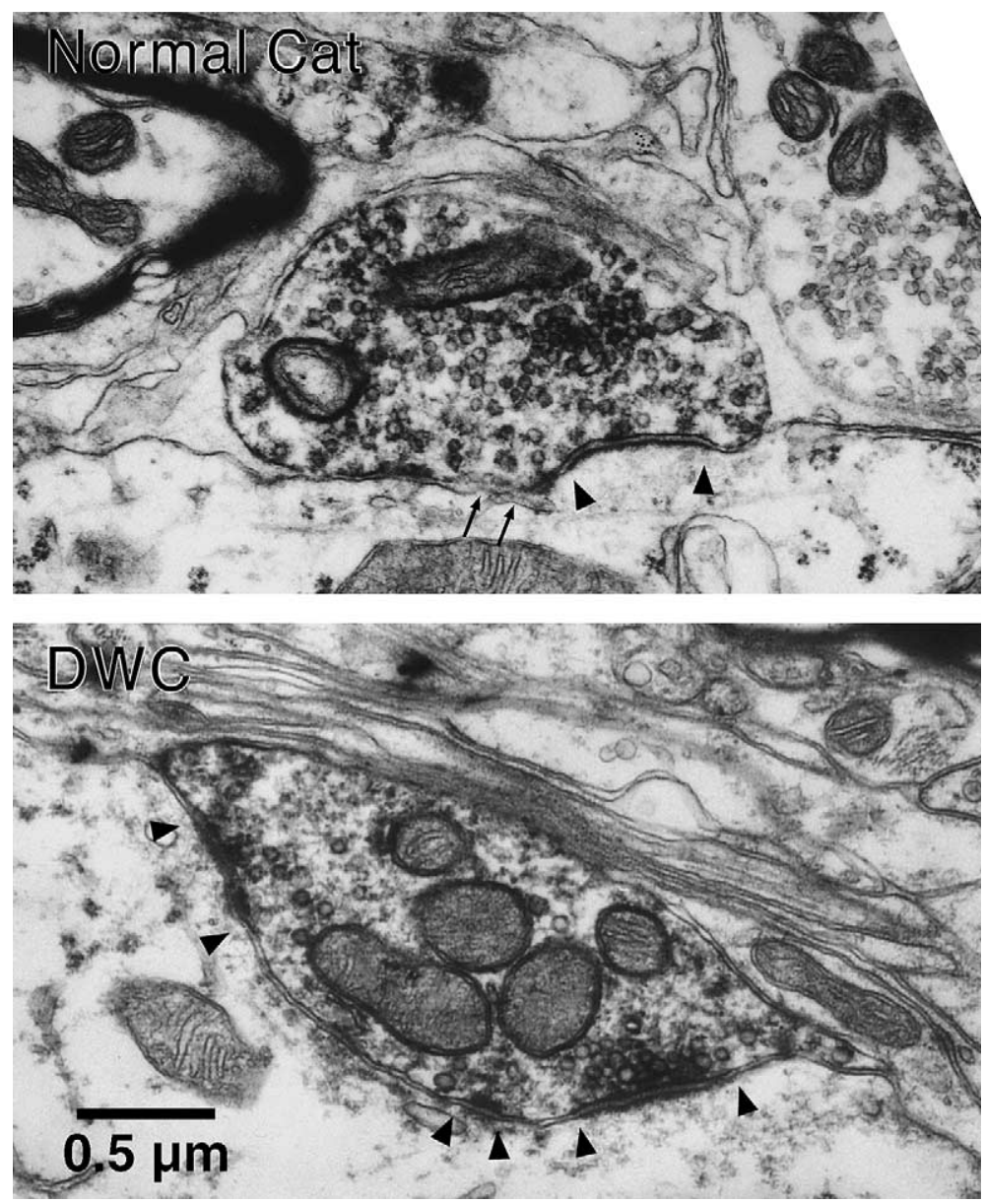

Fig. 12. Electron micrographs through pieces of endbulbs from a normal hearing cat (top) and congenitally deaf white cat (bottom). Endbulbs are filled with clear, round synaptic vesicles. (Top) In the normal hearing cat, a typical synapse (arrowheads) is punctate and characterized by a somatic convexity that bulges into the ending. There is a clear asymmetric postsynaptic membrane thickening and an adjacent intercellular cistern (small arrows). (Bottom) In the congenitally deaf white cat, a typical synapse is flattened and expanded in area when compared to that of normal cats, and the intercellular cisternae disappear. Reconstructions of postsynaptic densities through serial sections reveal that these specializations in congenitally deaf cats can, on average, be enlarged by more than double. Adapted from Ryugo et al. [172], Wiley-Liss publishers.

depleted of glutamate by potassium-induced depolarization. The production and/or utilization of glutamate is mediated by aspartate aminotransferase. The soluble cytoplasmic fraction of this amino acid has been immunolocalized to endings of auditory nerve fibers $[2,166]$. The presence of glutamate and one of its metabolic precursors in the presynaptic endings is complemented by glutamate receptors in cochlear nucleus neurons (e.g. [143,144,167,213,217]). These receptors include ionotropic receptors that are formed by several subunits surrounding a central ion channel, and metabotropic receptors that associate with G-proteins and tend to mediate long-term responses.

The ionotropic receptors include AMPA, kainate, delta, and NMDA types. AMPA receptors mediate the fast excitatory transmission and consist of four subunits, GluR1-4 with flip, flop, and other splice variants. Primary endings in the cochlear nucleus oppose AMPA receptors composed mainly of GluR3 and GluR4 [143,167,213]. The GluR4 subunits gate rapidly and are specialized for auditory nerve in- put [119]. The GluR2 subunits, which exhibit slower AMPA kinetics, are associated with parallel fiber inputs in the DCN [56]. Primary endings are also associated with delta receptors but it is not known if delta receptors form functional receptors.

NMDA receptors are characterized by a voltage-dependent calcium channel. It is thought that depolarization via the AMPA receptors is required for the NMDA receptor to open. The calcium-permeability of NMDA is presumed to form the basis of the long-term effects underlying learning and memory. There are a number of NMDA receptors, including NR1 (with eight splice variants), NR2A-D, and NR3. Receptors are composed of NR1 plus one or more variants of NR2 which determine their physiological properties. NR1 has a widespread distribution in the cochlear nucleus $[15,143]$. NR2A and NR2C are found in the superficial granule cell layer of the ventral cochlear nucleus and in medium sized neurons of the deeper layers of the DCN. NR2A is in the large neurons of the rostral AVCN 
and NR2B is in pyramidal cells of the DCN. There is pharmacologic evidence that reveals an early presence of NMDA receptors in the developing auditory system that diminishes shortly after weaning $[54,73]$. Such data indicate that NMDA receptors may play a role in the development of the non-NMDA receptors.

Metabotropic glutamate receptors are thought of as single molecules coupled to G-proteins. The G-proteins are linked to intracellular transduction pathways that may underlie plasticity. There are three types of metabotropic receptors based on their pharmacologic properties and second messenger cascades [126]. In the cochlear nucleus, immunocytochemical staining demonstrates labeling of mGluR $1 \alpha$ and mGluR5 [143], which are involved in the initiation of the phosphoinositol transduction pathway [127]. These metabotropic receptors are distributed in the perisynaptic membrane that flanks the postsynaptic membrane density $[128,145]$.

Transmitter released from auditory nerve endings must be rapidly removed from the synaptic cleft so that the postsynaptic cell is prepared for the next transmission. The removal and inactivation of neurotransmitter is accomplished by a highly efficient system of uptake and transporter molecules that surround glutamatergic synapses $[9,10,46]$. It has been speculated that glial processes and neuronal membranes lining the intercellular cisternae between primary endings and cochlear nucleus neurons might house the relevant transporter molecules [154]. Regulation of residual transmitter by glial transporters has been suggested as a means to control synaptic strength [210]. A preference for transporter molecules to be distributed along the membranes lining these perisynaptic cisternae could provide important insights into synaptic function.

\subsection{Microcneuronal shell}

Surrounding the magnocellular core of the cochlear nucleus is a thin shell of microneurons $[121,122,133,215]$. The outermost shell is represented by the GCD, a superficial layer of predominantly granule cells. The GCD forms a thin rind over the dorsal and lateral surface of the ventral cochlear nucleus, extending over the rostral pole backward to separate the VCN from the DCN. Within the GCD are also Golgi cells, unipolar brush cells, mitt cells, and chestnut cells. The unmyelinated type II auditory nerve fibers, which carry information from the outer hair cells of the cochlea, terminate among the granule cells [11,22], but the myelinated type I fibers do not $[23,51]$. The GCD does receive nonauditory inputs, including projections from the somatosensory cuneate nucleus [216,219], the trigeminal nuclei [74], the vestibular system $[25,26,84]$, and pontine nuclei [131]. Many of the inputs are in the form of mossy fiber endings $[65,122,131,219]$ and at least some are immunoreactive to the neurotransmitter, glutamate [219].

The GCD receives highly diverse inputs, and in turn, projects into the DCN. There have been ample observations that demonstrate detailed cellular similarities between the DCN, a cerebellar folium, and the fish electrosensory lateral line lobe $[6,103,114,120,121,122]$. The main inputs to these cerebellar-like structures are provided by afferents terminating on the basal dendrites of the principal cells, and granule cell axons through the superficial layer of the DCN as parallel fibers to terminate on the apical dendrites of the principal cells. Both inputs are excitatory and run orthogonally to one another. In the auditory system, they run longitudinally along the surface of the DCN, perpendicular to the isofrequency contours where they form excitatory synapses with the apical dendrites of pyramidal and cartwheel cells $[47,121,173,218]$. In this way, granule cells exert their influence upon pyramidal neurons that provide the main output for the nucleus [44,106,222]. Manipulations of the pinna proprioceptors, or electrical stimulation of cervical nerves $\mathrm{C} 1-\mathrm{C} 3$, have strong effects on the neural activity of DCN units, producing a reliable pattern of inhibition and excitation $[43,44,81]$. In fact, only stimuli that activated pinna muscle receptors (stretch or vibration of the muscles) were effective in activating DCN units. Light touch was ineffective in driving DCN units. These results are consistent with the hypothesis that the DCN has a role in coordinating pinna orientation to sound, or in correcting the effects of pinna movements on sound localization cues.

The projections of the DCN terminate in the inferior colliculus [132,134,176,191], a prominent midbrain structure involved in sensory-motor functions [35], stimulus subtraction for signal-to-noise enhancement [6], processing of acoustic motion [192,211], and acoustic plasticity $[79,104,220]$. Thus, there is ample evidence that connects GCD circuits with the integration of highly diverse information. It is perplexing, however, that primates, especially humans, exhibit less highly organized granule cell regions $[115,116]$. One could speculate that granule cell organization is related to the presence of a mobile pinna, but then where do burrow-dwelling mountain beavers fit into this scheme, with their hypertrophied GCD [112]? Clearly, there remains much to be learned about the microneuronal shell of the cochlear nucleus.

Situated immediately subjacent to the GCD lies what has been called the peripheral cap of small cells [133]. This peripheral margin contains small and medium-sized stellate cells with either spiny and smooth dendrites, Golgi cells, and granule cells [27]. This region receives strong input from low-SR type I auditory nerve fibers [51,100] as well as from collaterals of the medial olivocochlear efferents [7]. High-SR fibers do not project into the small cell cap [100]. The innervation of the small cell cap by low-SR fibers arises from thin collaterals off the parent branch. These collaterals can extend some distance beyond the endbulb to innervate the rostal extension of the small cell cap or arborize into the lateral margins of the cap. These highly ramified arborizations account for the greater collateral lengths and branching exhibited in the AVCN by the low-SR auditory nerve fibers (see Fig. 10B). 
The cells of the small cell region have low spontaneous discharge rates, and when driven by sound, exhibited wide dynamic range and pause-build and onset patterns [58]. The resident neurons reflect some of the physiologic characteristics of the low-SR fiber inputs, and those with wide dynamic ranges may be well suited to encode stimulus intensity. Moreover, the cap region projects to the superior olivary complex, including the medial olivocochlear efferent neurons [221], suggesting that it forms an important part of the medial olivocochlear efferent circuit to outer hair cells.

\section{Summary}

Analysis of auditory nerve fibers in birds and mammals reveals striking similarities and differences. In view of the 200 million years since these two classes diverged from their common ancestor, the similarities in auditory nerve characteristics are remarkable. The avian nerve is simpler than that of the mammal, but many fundamental principles of neural development, structure and function are shared. Perhaps because of the greater simplicity of the avian system, their study has brought many insights into the hearing of the mammals.

In humans, as in other mammals, there are two types of ganglion cells $[12,37,125,135]$. On the basis of cochlear nucleus cytoarchitecture $[4,116]$ and neuronal morphology [1], there is a strong suggestion that humans follow the general mammalian plan. In addition to morphology, the biochemistry, pharmacology, and genetics are similar. One of the impressive observations in the last decade is the similarity of animal genes across species, and that, for example, homologous genes in fruit flies and mice can produce hearing disorders that are found in humans. Thus, despite the relative dearth of data on the human auditory nerve, the collective results of animal studies demonstrate that we can learn much about the human condition by studying the auditory nerves of birds and mammals.

\section{Acknowledgements}

The authors wish to thank their colleagues and coworkers who contributed data to this project. We are especially grateful to Christine Köppl for pertinent discussions of issues, $M$. Christian Brown for helpful comments on the manuscript, and to Liana Rose for helping to organize the bibliography. The authors were supported in part by NIH Grants DC00232, DC04395, and DC00144.

\section{References}

[1] J.C. Adams, Neuronal morphology in the human cochlear nucleus, Arch. Otolaryngol. Head Neck Surg. 112 (1986) 1253-1261.

[2] R.A. Altschuler, G.R. Neises, G.G. Harmison, R.J. Wenthold, J. Fex, Immunocytochemical localization of aspartate aminotransferase immunoreactivity in cochlear nucleus of the guinea pig, Proc. Natl. Acad. Sci. U.S.A. 78 (1981) 6553-6557.

[3] B.M. Alving, W.M. Cowan, Some quantitative observations on the cochlear division of the eighth nerve in the squirrel monkey (Saimiri sciureus), Brain Res. 25 (1971) 229-239.

[4] R.D. Bacsik, N.L. Strominger, The cytoarchitecture of the human anteroventral cochlear nucleus, J. Comp. Neurol. 147 (1973) 281289.

[5] R. Bal, D. Oertel, Potassium currents in octopus cells of the mammalian cochlear nucleus, J. Neurophysiol. 86 (2001) 2299-2311.

[6] C.C. Bell, D. Bodznick, J. Montgomery, J. Bastian, The generation and subtraction of sensory expectations within cerebellum-like structures, Brain Behav. Evol. 50 (1997) 17-31.

[7] T.E. Benson, M.C. Brown, Synapses formed by olivocochlear axon branches in the mouse cochlear nucleus, J. Comp. Neurol. 295 (1990) 52-70.

[8] M.J. Benton, Vertebrate Paleontology, second ed., Chapman and Hall, London, 1997.

[9] D.E. Bergles, J.S. Diamond, C.E. Jahr, Clearance of glutamate inside the synapse and beyond, Curr. Opin. Neurobiol. 9 (1999) 293298.

[10] D.E. Bergles, J.A. Dzubay, C.E. Jahr, Glutamate transporter currents in bergmann glial cells follow the time course of extrasynaptic glutamate, Proc. Natl. Acad. Sci. U.S.A. 94 (1997) 1482114825.

[11] A.M. Berglund, M.C. Brown, Central trajectories of type-II spiral ganglion cells from various cochlear regions in mice, Hear. Res. 75 (1994) 121-130.

[12] A.M. Berglund, D.K. Ryugo, A monoclonal antibody labels type II neurons of the spiral ganglion, Brain Res. 383 (1986) 327-332.

[13] A.M. Berglund, D.K. Ryugo, Hair cell innervation by spiral ganglion cells in the mouse, J. Comp. Neurol. 255 (1987) 560-570.

[14] A.M. Berglund, D.K. Ryugo, Neurofilament antibodies and spiral ganglion neurons of the mammalian cochlea, J. Comp. Neurol. 306 (1991) 393-408.

[15] M.M. Bilak, S.R. Bilak, D.K. Morest, Differential expression of $\mathrm{N}$-methyl-D-aspartate receptor in the cochlear nucleus of the mouse, Neuroscience 75 (1996) 1075-1097.

[16] C.C. Blackburn, M.B. Sachs, Classification of unit types in the anteroventral cochlear nucleus: PST histograms and regularity analysis, J. Neurophysiol. 62 (1989) 1303-1329.

[17] R.L. Boord, G.L. Rasmussen, Projection of the cochlear and lagenar nerves on the cochlear nuclei of the pigeon, J. Comp. Neurol. 120 (1963) 463-473.

[18] T.R. Bourk, Electrical responses of neural units in the anteroventral cochlear nucleus of the cat, Ph.D. Dissertation, Massachusetts Institute of Technology, 1976.

[19] T.R. Bourk, J.P. Mielcarz, B.E. Norris, Tonotopic organization of the anteroventral cochlear nucleus of the cat, Hear. Res. 4 (1981) 215-241.

[20] J.R. Brawer, D.K. Morest, E.C. Kane, The neuronal architecture of the cochlear nucleus of the cat, J. Comp. Neurol. 155 (1974) 251-300.

[21] M.C. Brown, Morphology of labeled afferent fibers in the guinea pig cochlea, J. Comp. Neurol. 260 (1987) 591-604.

[22] M.C. Brown, A.M. Berglund, N.Y.-S. Kiang, D.K. Ryugo, Central trajectories of type II spiral ganglion neurons, J. Comp. Neurol. 278 (1988) 581-590.

[23] M.C. Brown, J.V. Ledwith, Projections of thin (type-II) and thick (type-I) auditory-nerve fibers into the cochlear nucleus of the mouse, Hear. Res. 49 (1990) 105-118.

[24] R.H. Browner, D. Marbey, The nucleus magnocellularis in the red-eared turtle, Chrysemys scripta elegans: eighth nerve endings and neuronal types, Hear. Res. 33 (1988) 257-271.

[25] D. Bukowska, Morphological evidence for secondary vestibular afferent connections to the dorsal cochlear nucleus in the rabbit, Cells Tissues Organs 170 (2002) 61-68. 
[26] M. Burian, W. Gstoettner, Projection of primary vestibular afferent fibers to the cochlear nucleus in the guinea pig, Neurosci. Lett. 84 (1988) 13-17.

[27] N.B. Cant, The synaptic organization of the ventral cochlear nucleus of the cat: the peripheral cap of small cells, in: E. Mugnaini (Ed.), The Mammalian Cochlear Nuclei: Organization and Function, Plenum Press, New York, 1993, pp. 91-105.

[28] N.B. Cant, D.K. Morest, The bushy cells in the anteroventral cochlear nucleus of the cat. A study with the electron microscope, Neuroscience 4 (1979) 1925-1945.

[29] C.E. Carr, R.E. Boudreau, The central projections of auditory nerve fibers in the barn owl, J. Comp. Neurol. 314 (1991) 306-318.

[30] C.E. Carr, R.E. Boudreau, Organization of the nucleus magnocellularis and the nucleus laminaris in the barn owl: encoding and measuring interaural time differences, J. Comp. Neurol. 334 (1993) $337-355$.

[31] C.E. Carr, R.E. Boudreau, Development of the time coding pathways in the auditory brainstem of the barn owl, J. Comp. Neurol. 373 (1996) 467-483.

[32] C.E. Carr, I. Fujita, M. Konishi, Distribution of GABAergic neuron and terminals in the auditory system of the barn owl, J. Comp. Neurol. 286 (1989) 190-207.

[33] C.E. Carr, D. Soares, S. Parameshwaran, T. Perney, Evolution and development of time coding systems, Curr. Opin. Neurobiol. 1 (2001) 727-733.

[34] R.L. Carroll, Vertebrate Paleontology and Evolution, Freeman, New York, 1988.

[35] J.H. Casseday, E. Covey, A neuroethological theory of the operation of the inferior colliculus, Brain Behav. Evol. 47 (1996) 311-336.

[36] L. Chen, R. Salvi, M. Shero, Cochlear frequency-place map in adult chickens: intracellular biocytin labeling, Hear. Res. 81 (1994) 130-136.

[37] C.M. Chiong, B.J. Burgess, J.B.J. Nadol, Postnatal maturation of human spiral ganglion cells: light and electron microscopic observations, Hear. Res. 67 (1993) 211-219.

[38] R.A. Code, L. Churchill, $\mathrm{GABA}_{\mathrm{A}}$ receptors in auditory brainstem nuclei of the chick during development and after cochlea removal, Hear. Res. 54 (1991) 281-295.

[39] R.A. Code, E.W. Rubel, Glycine-immunoreactivity in the auditory brain stem of the chick, Hear. Res. 40 (1989) 167-172.

[40] J.W. Conlee, T. Parks, Late appearance and deprivation-sensitive growth of permanent dendrites in the avian cochlear nucleus (Nuc Magnocellularis), J. Comp. Neurol. 217 (1983) 216-226.

[41] P.J. Conn, J.P. Pin, Pharmacology and functions of metabotropic glutamate receptors, Annu. Rev. Pharmacol. Toxicol. 37 (1997) 205-237.

[42] J. Dau, R.J. Wenthold, Immunocytochemical localization of neurofilament subunits in the spiral ganglion of normal and neomycintreated guinea pigs, Hear. Res. 42 (1989) 253-263.

[43] K.A. Davis, R.L. Miller, E.D. Young, Effects of somatosensory and parallel-fiber stimulation on neurons in dorsal cochlear nucleus, J. Neurophysiol. 76 (1996) 3012-3024.

[44] K.A. Davis, E.D. Young, Pharmacological evidence of inhibitory and disinhibitory neuronal circuits in dorsal cochlear nucleus, J. Neurophysiol. 83 (2000) 926-940.

[45] G. Despres, G.P. Leger, D. Dahl, R. Romand, Distribution of cytoskeletal proteins (neurofilaments peripherin and MAP-tau) in the cochlea of the human fetus, Acta Otolaryngol. 114 (1994) 377-381.

[46] J.S. Diamond, C.E. Jahr, Transporters buffer synaptically released glutamate on a submillisecond time scale, J. Neurosci. 17 (1997) $4672-4687$.

[47] J.R. Doucet, D.K. Ryugo, Projections from the ventral cochlear nucleus to the dorsal cochlear nucleus in rats, J. Comp. Neurol. 385 (1997) 245-264.

[48] G. Ehret, Quantitative analysis of nerve fibre densities in the cochlea of the house mouse (Mus musculus), J. Comp. Neurol. 183 (1979) 73-88.
[49] E.F. Evans, The frequency response and other properties of single fibers in the guinea-pig cochlea, J. Physiol. 226 (1972) 263-287.

[50] E.F. Evans, A.R. Palmer, Relationship between the dynamic range of cochlear nerve fibres and their spontaneous activity, Exp. Brain Res. 40 (1980) 115-118.

[51] D.M. Fekete, E.M. Rouiller, M.C. Liberman, D.K. Ryugo, The central projections of intracellularly labeled auditory nerve fibers in cats, J. Comp. Neurol. 229 (1984) 432-450.

[52] F.P. Fischer, B. Eisensamer, G.A. Manley, Cochlear and lagenar ganglia of the chicken, J. Morphol. 220 (1994) 71-83.

[53] E. Friauf, J. Ostwald, Divergent projections of physiologically characterized rat ventral cochlear nucleus neurons as shown by intra-axonal injection of horseradish peroxidase, Exp. Brain Res. 73 (1988) 263-284.

[54] K. Futai, M. Okada, K. Matsuyama, T. Takahashi, High-fidelity transmission acquired via a developmental decrease in NMDA receptor expression at an auditory synapse, J. Neurosci. 21 (2001) 3342-3349.

[55] R.R. Gacek, G.L. Rasmussen, Fiber analysis of the statoacoustic nerve of guinea pig, cat and monkey, Anat. Rec. 139 (1961) 455463.

[56] S.M. Gardner, L.O. Trussell, D. Oertel, Time course and permeation of synaptic AMPA receptors in cochlear nuclear neurons correlate with input, J. Neurosci. 19 (1999) 8721-8729.

[57] J.R. Geiger, T. Melcher, D.S. Koh, B. Sakmann, P.H. Seeburg, P. Jonas, H. Monyer, Relative abundance of subunit mRNAs determines gating and $\mathrm{Ca}^{2+}$ permeability of AMPA receptors in principal neurons and interneurons in rat CNS, Neuron 15 (1995) 193-204.

[58] S. Ghoshal, D.O. Kim, Marginal shell of the anteroventral cochlear nucleus: single-unit response properties in the unanesthetized decerebrate cat, J. Neurophysiol. 77 (1997) 2083-2097.

[59] D.J. Gibson, E.D. Young, J.A. Costalupes, Similarity of dynamic range adjustment in auditory nerve and cochlear nuclei, J. Neurophysiol. 53 (1985) 940-958.

[60] R.D. Ginzberg, D.K. Morest, A study of cochlear innervation in the young cat with the Golgi method, Hear. Res. 10 (1983) 227-246.

[61] N.L. Golding, M.J. Ferragamo, D. Oertel, Role of intrinsic conductances underlying responses in octopus cells of the cochlear nucleus, J. Neurophysiol. 19 (1999) 2897-2905.

[62] F.H. Güldner, S.C. Phillips, Structural plasticity of synaptic contacts in the central nervous system, in: D.G. Jones (Ed.), Current Topic in Research on Synapses, vol. 3, Liss, New York, 1986, pp. 147-169.

[63] R.L. Gulley, D.M.D. Landis, T.S. Reese, Internal organization of membranes at endbulbs of Held in the anteroventral cochlear nucleus, J. Comp. Neurol. 180 (1978) 707-742.

[64] C.M. Hackney, K.K. Osen, O.P. Ottersen, J. Storm-Mathisen, G Manjaly, Immunocytochemical evidence that glutamate is a neurotransmitter in the cochlear nerve: a quantitative study in the guinea-pig anteroventral cochlear nucleus, Eur. J. Neurosci. 8 (1996) 79-91.

[65] C.-A. Haenggeli, J.R. Doucet, D.K. Ryugo, Trigeminal projections to the cochlear nucleus in rats, ARO Abstr. 25 (2002) 7.

[66] A. Hafidi, Peripherin-like immunoreactivity in type II spiral ganglion cell body and projections, Brain Res. 805 (1998) 181-190.

[67] A. Hafidi, G. Despres, R. Romand, Ontogenesis of type II spiral ganglion neurons during development: peripherin immunohistochemistry, Int. J. Dev. Neurosci. 11 (1993) 507-512.

[68] J.M. Harrison, R. Irving, The organization of posteroventral cochlear nucleus in the rat, J. Comp. Neurol. 126 (1966) 391-402.

[69] U.H. Hausler, W.E. Sullivan, D. Soares, C.E. Carr, A morphological study of the cochlear nuclei of the pigeon (Columba livia), Brain Behav. Evol. 54 (1999) 290-302.

[70] H. Held, Die Centrale Gehörleitung., Arch. Anat. Physiol. Anat. Abstr. (1893) 201-248.

[71] L.B. Hurd, K.A. Hutson, D.K. Morest, Cochlear nerve projections to the small cell shell of the cochlear nucleus: the neuroanatomy of extremely thin sensory axons, Synapse 33 (1999) 83-117. 
[72] Y. Ibata, G.D. Pappas, The fine structure of synapses in relation to the large spherical neurons in the anterior ventral cochlear (sic) of the cat, J. Neurocytol. 5 (1976) 395-406.

[73] J.S. Issacson, B. Walmsley, Receptors underlying excitatory synaptic transmission in slices of the rat anteroventral cochlear nucleus, J. Neurophysiol. 73 (1995) 964-973.

[74] K. Itoh, H. Kamiya, A. Mitani, Y. Yasui, M. Takada, N. Mizuno, Direct projections from the dorsal column nuclei and the spinal trigeminal nuclei to the cochlear nuclei in the cat, Brain Res. 400 (1987) $145-150$.

[75] H. Jackson, E.F. Nemeth, T.N. Parks, Non- $N$-methyl-D-aspartate receptors mediating synaptic transmission in the avian cochlear nucleus: effects of kynurenic acid, dipicolinic acid and streptomycin, Neuroscience 16 (1985) 171-179.

[76] H. Jackson, T. Parks, Functional synapse elimination in the developing avian cochlear nucleus with simultaneous reduction in cochlear nerve axon branching, J. Neurosci. 2 (1982) 1736-1743.

[77] S. Jhaveri, D.K. Morest, Neuronal architecture in nucleus magnocellularis of the chicken auditory system with observations on nucleus laminaris: a light and electron microscope study, Neuroscience 7 (1982) 809-836.

[78] S. Jhaveri, D.K. Morest, Sequential alterations of neuronal architecture in nucleus magnocellularis of the developing chicken: a Golgi study, Neuroscience 7 (1982) 837-853.

[79] W. Ji, E. Geo, N. Suga, Effects of acetylcholine and atropine on plasticity of central auditory neurons caused by conditioning in bats, J. Neurophysiol. 86 (2001) 211-225.

[80] A. Kaiser, G.A. Manley, Brainstem connections of the macula lagena in the chicken, J. Comp. Neurol. 374 (1996) 101-117.

[81] P.O. Kanold, E.D. Young, Proprioceptive information from the pinna provides somatosensory input to cat dorsal cochlear nucleus, J. Neurosci. 21 (2001) 7848-7858.

[82] T. Kawase, M.C. Liberman, Spatial organization of the auditory nerve according to spontaneous discharge rate, J. Comp. Neurol. 319 (1992) 312-318.

[83] E.M. Keithley, M.L. Feldman, Spiral ganglion cell counts in an age-graded series of rat cochleas, J. Comp. Neurol. 188 (1979) 429-442.

[84] G.A. Kevetter, A.A. Perachio, Projections from the sacculus to the cochlear nuclei in the Mongolian gerbil, Brain Behav. Evol. 34 (1989) 193-200.

[85] N.Y.-S. Kiang, M.C. Liberman, J.S. Gage, C.C. Northrup, L.W. Dodds, M.E. Oliver, Afferent innervation of the mammalian cochlea, in: H.P. Maddrell (Ed.), Comparative Physiology of Sensory Systems, Cambridge University Press, Cambridge, 1984, pp. 143-161.

[86] N.Y.-S. Kiang, D.K. Morest, D.A. Godfrey, J.J. Guinan Jr., E.C. Kane, Stimulus coding at caudal levels of the cat's auditory nervous system. I. Response characteristics of single units, in: A.R. Moller (Ed.), Basic Mechanisms of Hearing, Academic Press, New York, 1973, pp. 455-478.

[87] N.Y.-S. Kiang, J.M. Rho, C.C. Northrop, M.C. Liberman, D.K. Ryugo, Hair-cell innervation by spiral ganglion cells in adult cats, Science 217 (1982) 175-177.

[88] N.Y.-S. Kiang, T. Watanabe, E.C. Thomas, L.F. Clark, Discharge Patterns of Single Fibers in the Cat's Auditory Nerve, MIT Press, Cambridge, MA, 1965.

[89] M. Konishi, Comparative neurophysiological studies of hearing and vocalization in songbirds, Z. Vergl. Physiol. 66 (1970) 257272.

[90] C. Köppl, Auditory nerve terminals in the cochlear nucleus magnocellularis: differences between low and high frequencies, J. Comp. Neurol. 339 (1994) 438-446.

[91] C. Köppl, Number and axon calibers of cochlear afferents in the barn owl, Audiol. Neurosci. 3 (1997) 331-334.

[92] C. Köppl, Frequency tuning and spontaneous activity in the auditory nerve and cochlear nucleus magnocellularis of the barn owl, Tyto alba, J. Neurophysiol. 77 (1997) 364-377.
[93] C. Köppl, Tonotopic projections of the auditory nerve to the cochlear nucleus angularis in the barn owl, JARO 2 (2001) 41-53.

[94] P.A. Leake, R.L. Snyder, Topographic organization of the central projections of the spiral ganglion in cats, J. Comp. Neurol. 281 (1989) 612-629.

[95] N.J. Lenn, T.S. Reese, The fine structure of nerve endings in the nucleus of the trapezoid body and the ventral cochlear nucleus, Am. J. Anat. 118 (1966) 375-390.

[96] M.D. Levin, M.F. Kubke, M. Schneider, R.J. Wenthold, C.E. Carr, Localization of AMPA-selective glutamate receptors in the auditory brainstem of the barn owl, J. Comp. Neurol. 378 (1997) 239-253.

[97] M.C. Liberman, Auditory-nerve response from cats raised in a low-noise chamber, J. Acoust. Soc. Am. 63 (1978) 442-455.

[98] M.C. Liberman, The cochlear frequency map for the cat: labeling auditory-nerve fibers of known characteristic frequency, J. Acoust. Soc. Am. 75 (1982) 1441-1449.

[99] M.C. Liberman, Single neuron labelling in the cat auditory nerve, Science 216 (1982) 1239-1241.

[100] M.C. Liberman, Central projections of auditory-nerve fibers of differing spontaneous rate. I. Anteroventral cochlear nucleus, J. Comp. Neurol. 313 (1991) 240-258.

[101] M.C. Liberman, Central projections of auditory-nerve fibers of differing spontanteous rate. II. Posterovental and dorsal cochlear nuclei, J. Comp. Neurol. 327 (1993) 17-36.

[102] C.J. Limb, D.K. Ryugo, Primary axosomatic endings in the anteroventral cochlear nucleus of mice: development and deafness, JARO 1 (2000) 103-119.

[103] R. Lorente de Nó, The Primary Acoustic Nuclei, Raven Press, New York, 1981.

[104] X. Ma, N. Suga, Plasticity of bat's central auditory system evoked by focal electric stimulation of auditory and/or somatosensory cortices, J. Neurophysiol. 85 (2001) 1078-1087.

[105] B.B. Mandelbrot, The Fractal Geometry of Nature, Freeman, New York, 1982.

[106] P.B. Manis, Responses to parallel fiber stimulation in the guinea pig dorsal cochlear nucleus in vitro, J. Neurophysiol. 61 (1989) 149-161.

[107] P.B. Manis, Membrane properties and discharge characteristics of guinea pig dorsal cochlear nucleus neurons studied in vitro, J. Neurosci. 10 (1990) 2338-2351.

[108] P.B. Manis, S.O. Marx, Outward currents in isolated ventral cochlear nucleus neurons, J. Neurosci. 11 (1991) 2865-2880.

[109] G.A. Manley, O. Gleich, H.J. Leppelsack, H. Oeckinghaus, Activity patterns of cochlear ganglion neurones in the starling, J. Comp. Physiol. A 157 (1985) 161-181.

[110] B.J. May, A.Y. Huang, G.S. Le Prell, R.D. Heinz, Vowel formant frequency discrimination in cats: comparison of auditory nerve representations and psychophysical thresholds, Audiol. Neurosci. 3 (1996) 135-162.

[111] A. Merchan-Perez, M.C. Liberman, Ultrastructural differences among afferent synapses on cochlear hair cells: correlations with spontaneous discharge rate, J. Comp. Neurol. 371 (1996) 208221.

[112] M.M. Merzenich, L. Kitzes, L. Aitkin, Anatomical and physiological evidence for auditory specialization in the mountain beaver (Aplodontia rufa), Brain Res. 58 (1973) 331-344.

[113] A. Moiseff, M. Konishi, Neuronal and behavioral sensitivity to binaural time differences in the owl, J. Neurosci. 1 (1981) 25532562.

[114] J.C. Montgomery, S. Coombs, R.A. Conley, D. Bodznick, Hindbrain sensory processing in lateral line, electrosensory, and auditory systems: a comparative overview of anatomical and functional similarities, Audiol. Neurosci. 1 (1995) 207-231.

[115] J.K. Moore, The primate cochlear nuclei: loss of lamination as a phylogenetic process, J. Comp. Neurol. 193 (1980) 609-629.

[116] J.K. Moore, K.K. Osen, The cochlear nuclei in man, Am. J. Anat. 154 (1979) 393-418. 
[117] D.K. Morest, N.Y.-S. Kiang, E.C. Kane, J.J. Guinan Jr., D.A. Godfrey, Stimulus coding at caudal levels of the cat's auditory nervous system. II. Pattern of synaptic organization, in: A.R. Moller (Ed.), Basic Mechanisms of Hearing, Academic Press, New York, 1973, pp. 479-504.

[118] Y.V. Morgan, D.K. Ryugo, M.C. Brown, Central trajectories of type II (thin) fibers of the auditory nerve in cats, Hear. Res. 79 (1994) $74-82$.

[119] J. Mosbacher, R. Schoepfer, H. Monyer, N. Burnashev, P.H. Seeburg, J.P. Ruppersberg, A molecular determinant for submillisecond desensitization in glutamate receptors, Science 266 (1994) 10591062.

[120] E. Mugnaini, J.I. Morgan, The neuropeptide cerebellin is a marker for two similar neuronal circuits in rat brain, Proc. Natl. Acad. Sci. U.S.A. 84 (1987) 8692-8696.

[121] E. Mugnaini, K.K. Osen, A.L. Dahl, V.L. Friedrich Jr., G. Korte, Fine structure of granule cells and related interneurons (termed Golgi cells) in the cochlear nuclear complex of cat, rat, and mouse, J. Neurocytol. 9 (1980) 537-570.

[122] E. Mugnaini, W.B. Warr, K.K. Osen, Distribution and light microscopic features of granule cells in the cochlear nuclei of cat, rat, and mouse, J. Comp. Neurol. 191 (1980) 581-606.

[123] C.M. Muller, Gamma-aminobutyric acid immunoreactivity in brainstem auditory nuclei of the chicken, Neurosci. Lett. 77 (1987) 272276.

[124] F.T. Munzer, Über markhaltige Ganglienzellen, Z. Mikrosk. Anat. Forsch. 24 (1931) 286-361.

[125] J.B.J. Nadol, B.J. Burgess, C. Reisser, Morphometric analysis of normal human spiral ganglion cells, Ann. Otol. Rhinol. Laryngol. 99 (1990) 340-348.

[126] S. Nakanishi, The molecular diversity of glutamate receptors, Prog. Clin. Biol. Res. 390 (1994) 85-98.

[127] S. Nakanishi, Y. Nakajima, M. Masu, Y. Ueda, K. Nakahara, D. Watanabe, S. Yamaguchi, S. Kawabata, M. Okada, Glutamate receptors: brain function and signal transduction, Brain Res. Brain Res. Rev. 26 (1998) 230-235.

[128] Z. Nusser, E. Mulvihill, P. Streit, P. Somogyi, Subsynaptic segregation of metabotropic and ionotropic glutamate receptors as revealed by immunogold localization, Neuroscience 61 (1994) 421427.

[129] D. Oertel, The role of intrinsic neuronal properties in the encoding of auditory information in the cochlear nuclei, Curr. Opin. Neurobiol. 1 (1991) 221-228.

[130] D. Oertel, Encoding of timing in the brain stem auditory nuclei of vertebrates, Neuron 19 (1997) 959-962.

[131] M. Ohlrogge, J.R. Doucet, D.K. Ryugo, Projections of the pontine nuclei to the cochlear nucleus in rats, J. Comp. Neurol. 436 (2001) 290-303.

[132] D.L. Oliver, Quantitative analyses of axonal endings in the central nucleus of the inferior colliculus and distribution of $3 \mathrm{H}$-labeling after injections in the dorsal cochlear nucleus, J. Comp. Neurol. 237 (1985) 343-359.

[133] K.K. Osen, Cytoarchitecture of the cochlear nuclei in the cat, J. Comp. Neurol. 136 (1969) 453-482.

[134] K.K. Osen, Projection of the cochlear nuclei on the inferior colliculus in the cat, J. Comp. Neurol. 144 (1972) 355-372.

[135] C.Y. Ota, R.S. Kimura, Ultrastructural study of the human spiral ganglion, Acta Otolaryngol. 89 (1980) 53-62.

[136] T.S. Otis, I.R. Raman, L.O. Trussell, AMPA receptors with high $\mathrm{Ca}^{2+}$ permeability mediate synaptic transmission in the avian auditory pathway, J. Physiol. 482 (1995) 309-315.

[137] T. Parks, Effects of early deafness on development of brain stem auditory neurons, Ann. Otol. Rhinol. Laryngol. Suppl. 168 (1997) $37-43$.

[138] T.N. Parks, Changes in the length and organization of nucleus laminaris dendrites after unilateral otocyst ablation in chick embryos, J. Comp. Neurol. 202 (1981) 47-57.
[139] T.N. Parks, The AMPA receptors of auditory neurons, Hear. Res. 147 (2000) 77-91.

[140] T.N. Parks, E.W. Rubel, Organization and development of the brain stem auditory nuclei of the chicken: primary afferent projections, J. Comp. Neurol. 180 (1978) 439-448.

[141] T.N. Parks, D.A. Taylor, Altered distribution of synaptic densities at aberrant synapses in the chick cochlear nucleus, Neurosci. Lett. 150 (1993) 117-121.

[142] T.N. Parks, D.A. Taylor, H. Jackson, Adaptations of synaptic form in an aberrant projection to the avian cochlear nucleus, J. Neurosci. 10 (1990) 975-984.

[143] R.S. Petralia, M.E. Rubio, Y.-X. Wang, R.J. Wenthold, Differential distribution of glutamate receptors in the cochlear nuclei, Hear. Res. 147 (2000) 59-69.

[144] R.S. Petralia, Y.-X. Wang, H.-M. Zhao, R.J. Wenthold, Ionotropic and metabotropic glutamate receptors show unique postsynaptic, presynaptic, and glial localizations in the dorsal cochlear nucleus, J. Comp. Neurol. 372 (1996) 356-383.

[145] R.S. Petralia, H.M. Zhao, Y.-X. Wang, R.J. Wenthold, Variations in the tangential distribution of postsynaptic glutamate receptors in Purkinje cell parallel and climbing fiber synapses during development, Neuropharmacology 37 (1998) 1321-1334.

[146] R.R. Pfeiffer, Anteroventral cochlear nucleus: wave forms of extracellularly recorded spike potentials, Science 154 (1966) 667-668.

[147] R.R. Pfeiffer, Classification of response patterns of spike discharges for units in the cochlear nucleus: tone burst stimulation, Exp. Brain Res. 1 (1966) 220-235.

[148] T.P.S. Powell, S.D. Erulkar, Transneuronal cell degeneration in the auditory relay nuclei of the cat, J. Anat. 96 (1962) 219-268.

[149] I.R. Raman, L.O. Trussell, The kinetics of the responses to glutamate and kainate in neurons of the avian cochlear nucleus, Neuron 9 (1992) 173-186.

[150] I.R. Raman, S. Zhang, L.O. Trussell, Pathway-specific variants of AMPA receptors and their contribution to neuronal signaling, J. Neurosci. 14 (1994) 4998-5010.

[151] R. Ramón y Cajal, Histologie du Système Nerveux de l'Homme et des Vertébrés, Instituto Ramón y Cajal, Madrid, 1909.

[152] G.L. Rasmussen, Studies of eighth cranial nerve of man, Laryngoscope 50 (1940) 67-83.

[153] A. Ravindranathan, S.D. Donevan, S.G. Sugden, A. Grieg, M.S. Rao, T.N. Parks, Contrasting molecular composition and channel properties of AMPA receptors on chick auditory and brainstem motor neurons, J. Physiol. 523 (2000) 667-684.

[154] E.E. Redd, T. Pongstaporn, D.K. Ryugo, The effects of congenital deafness on auditory nerve synapses and globular bushy cells in cats, Hear. Res. 147 (2000) 160-174.

[155] S. Rees, F.H. Guldner, L. Atikin, Activity dependent plasticity of postsynaptic density structure in the ventral cochlear nucleus of the rat, Brain Res. 325 (1985) 370-374.

[156] W.S. Rhode, S. Greenberg, Physiology of the cochlear nuclei, in: R.R. Fay (Ed.), The Mammalian Auditory Pathway: Neurophysiology, Springer, New York, 1992, pp. 94-152.

[157] W.S. Rhode, D. Oertel, P.H. Smith, Physiological response properties of cells labeled intracellularly with horseradish peroxidase in cat ventral cochlear nucleus, J. Comp. Neurol. 213 (1983) 448-463.

[158] W.S. Rhode, P.H. Smith, D. Oertel, Physiological response properties of cells labeled intracellularly with horseradish peroxidase in cat dorsal cochlear nucleus, J. Comp. Neurol. 213 (1983) 426-447.

[159] R. Romand, G. Ehret, Development of tonotopy in the inferior colliculus. I. Electrophysiological mapping in house mice, Dev. Brain Res. 54 (1990) 221-234.

[160] J.E. Rose, R. Galambos, J.R. Hughes, Microelectrode studies of the cochlear nuclei of the cat, Bull. Johns Hopkins Hospital 104 (1959) 211-251.

[161] G.L. Roth, L.M. Aitken, R.A. Anderson, M.M. Merzenich, Some features of the spatial organization of the central nucleus of the inferior colliculus of the cat, J. Comp. Neurol. 182 (1978) 661-680. 
[162] J.S. Rothman, E.D. Young, P.B. Manis, Convergence of auditory nerve fibers onto bushy cells in the ventral cochlear nucleus: implications of a computational model, J. Neurophysiol. 70 (1993) $2562-2583$

[163] E.M. Rouiller, R. Cronin-Schreiber, D.M. Fekete, D.K. Ryugo, The central projections of intracellularly labeled auditory nerve fibers in cats: an analysis of terminal morphology, J. Comp. Neurol. 249 (1986) 261-278.

[164] E.M. Rouiller, D.K. Ryugo, Intracellular marking of physiologically characterized cells in the ventral cochlear nucleus of the cat, J. Comp. Neurol. 225 (1984) 167-186.

[165] E.W. Rubel, T.N. Parks, Organization and development of brain stem auditory nuclei of the chicken: tonotopic organization of $n$. magnocellularis and n. laminaris, J. Comp. Neurol. 164 (1975) 411-433.

[166] M.E. Rubio, J.M. Juiz, Chemical anatomy of excitatory endings in the dorsal cochlear nucleus of the rat: differential synaptic distribution of aspartate aminotransferase, glutamate, and vesicular zinc, J. Comp. Neurol. 399 (1998) 341-358.

[167] M.E. Rubio, J.R. Wenthold, Glutamate receptors are selectively targeted to postsynaptic sites in neurons, Neuron 18 (1997) 939950.

[168] D.K. Ryugo, The auditory nerve: peripheral innervation, cell body morphology, and central projections, in: R.R. Fay (Ed.), The Mammalian Auditory Pathway: Neuroanatomy, Springer, New York, 1992, pp. 23-65.

[169] D.K. Ryugo, L.W. Dodds, T.E. Benson, N.Y.-S. Kiang, Unmyelinated axons of the auditory nerve in cats, J. Comp. Neurol. 308 (1991) 209-223.

[170] D.K. Ryugo, D.M. Fekete, Morphology of primary axosomatic endings in the anteroventral cochlear nucleus of the cat: a study of the endbulbs of Held, J. Comp. Neurol. 210 (1982) 239-257.

[171] D.K. Ryugo, S.K. May, The projections of intracellularly labeled auditory nerve fibers to the dorsal cochlear nucleus of cats, J. Comp. Neurol. 329 (1993) 20-35.

[172] D.K. Ryugo, T. Pongstaporn, D.M. Huchton, J.K. Niparko, Ultrastructural analysis of primary endings in deaf white cats: morphologic alterations in endbulbs of Held, J. Comp. Neurol. 385 (1997) 230-244.

[173] D.K. Ryugo, T. Pongstaporn, D.D. Wright, A.H. Sharp, Inositol 1,4,5-trisphosphate receptors: immunocytochemical localization in the dorsal cochlear nucleus, J. Comp. Neurol. 358 (1995) 102-118.

[174] D.K. Ryugo, B.T. Rosenbaum, P.J. Kim, J.K. Niparko, A.A. Saada, Single unit recordings in the auditory nerve of congenitally deaf white cats: morphological correlates in the cochlea and cochlear nucleus, J. Comp. Neurol. 397 (1998) 532-548.

[175] D.K. Ryugo, S. Sento, Synaptic connections of the auditory nerve in cats: relationship between endbulbs of Held and spherical bushy cells, J. Comp. Neurol. 305 (1991) 35-48.

[176] D.K. Ryugo, F.H. Willard, D.M. Fekete, Differential afferent projections to the inferior colliculus from the cochlear nucleus in the albino mouse, Brain Res. 210 (1981) 342-349.

[177] D.K. Ryugo, D.D. Wright, T. Pongstaporn, Ultrastructural analysis of synaptic endings of auditory nerve fibers in cats: correlations with spontaneous discharge rate, in: D.A. Godfrey (Ed.), The Mammalian Cochlear Nuclei: Organization and Function, Plenum Press, New York, 1993, pp. 65-74.

[178] D.K. Ryugo, M.M. Wu, T. Pongstaporn, Activity-related features of synapse morphology: a study of endbulbs of Held, J. Comp. Neurol. 365 (1996) 141-158.

[179] M.B. Sachs, P.J. Abbas, Rate versus level functions for auditorynerve fibers in the cat: tone-burst stimuli, J. Acoust. Soc. Am. 56 (1974) 1835-1847.

[180] M.B. Sachs, R.L. Winslow, C.C. Blackburn, Representation of speech in the auditory periphery, in: W.M. Cowan (Ed.), Auditory Function: Neurobiological Bases of Hearing, Wiley, New York, 1988, pp. $747-774$
[181] M.B. Sachs, N.K. Woolf, J.M. Sinnott, Response properties of neurons in the avian auditory system: comparisons with mammalian homologues and consideration of the neural encoding of complex stimuli, in: R.R. Fay (Ed.), Comparative Studies of Hearing in Vertebrates, Springer, New York, 1980, pp. 323-353.

[182] R.J. Salvi, S.S. Saunders, N.L. Powers, F.A. Boettcher, Discharge patterns of cochlear ganglion neurons in the chicken, J. Comp. Physiol. A 170 (1992) 227-241.

[183] R.A. Schmiedt, Spontaneous rates, thresholds and tuning of auditory-nerve fibers in the gerbil: comparisons to cat data, Hear. Res. 42 (1989) 23-36.

[184] C.E. Schreiner, H.L. Read, M.L. Sutter, Modular organization of frequency integration in primary auditory cortes, Annu. Rev. Neurosci. 23 (2000) 501-529.

[185] S. Sento, D.K. Ryugo, Endbulbs of Held and spherical bushy cells in cats: morphological correlates with physiological properties, J. Comp. Neurol. 280 (1989) 553-562.

[186] S.A. Shamma, J.W. Fleshman, P.R. Wiser, H. Versnel, Organization of response areas in ferret primary auditory cortex, J. Neurophysiol. 69 (1993) 367-383.

[187] D.J. Smith, E.W. Rubel, Organization and development of brain stem auditory nuclei of the chicken: dendritic gradients in nucleus laminaris, J. Comp. Neurol. 186 (1979) 213-239.

[188] D. Soares, C.E. Carr, The cytoarchitecture of the nucleus angularis of the barn owl (Tyto alba), J. Comp. Neurol. 429 (2001) 192-205.

[189] W.B. Spatz, E. Lohle, Calcium-binding proteins in the spiral ganglion of the monkey, Callithrix jacchus, Hear. Res. 86 (1995) 89-99.

[190] G.A. Spirou, W.E. Brownell, M. Zidanic, Recordings from cat trapezoid body and HRP labeling of globular bushy cell axons, J. Neurophysiol. 63 (1990) 1169-1190.

[191] G.A. Spirou, B.J. May, D.D. Wright, D.K. Ryugo, Frequency organization of the dorsal cochlear nucleus in cats, J. Comp. Neurol. 329 (1993) 36-52.

[192] M.W. Spitzer, M.N. Semple, Responses of inferior colliculus neurons to time-varying interaural phase disparity: effects of shifting the locus of virtual motion, J. Neurophysiol. 69 (1993) 3062-3076.

[193] H. Spoendlin, Degeneration behaviour of the cochlear nerve, Arch. Klin. Exp. Ohren Nasen Kehlkopfheilkd. 200 (1971) 275-291.

[194] H. Spoendlin, The innervation of the cochlea receptor, in: A.R. Moller (Ed.), Mechanisms in Hearing, Academic Press, New York, 1973, pp. 185-229.

[195] S.S. Stevens, H. Davis, Hearing, Its Psychology and Physiology, Wiley, New York, 1938.

[196] S.G. Sugden, L. Zirpel, C.J. Dietrich, T.N. Parks, Development of the specialized AMPA receptors of auditory neurons, J. Neurobiol. 52 (2002) 189-202.

[197] W.E. Sullivan, Classification of response patterns in cochlear nucleus of barn owl: correlation with functional response properties, J. Neurophysiol. 53 (1985) 201-216.

[198] W.E. Sullivan, M. Konishi, Segregation of stimulus phase and intensity in the cochlear nucleus of the barn owl, J. Neurosci. 4 (1984) 1787-1799.

[199] M.R. Szpir, S. Sento, D.K. Ryugo, The central progections of the cochlear nerve fibers in the alligator lizard, J. Comp. Neurol. 295 (1990) 530-547.

[200] T. Takahashi, A. Moiseff, M. Konishi, Time and intensity cues are processed independently in the auditory system of the owl, J. Neurosci. 4 (1984) 1781-1786.

[201] T.T. Takahashi, M. Konishi, Projections of nucleus angularis and nucleus laminaris to the lateral lemniscal nuclear complex of the barn owl, J. Comp. Neurol. 274 (1988) 212-238.

[202] L.P. Tolbert, D.K. Morest, The neuronal architecture of the anteroventral cochlear nucleus of the cat in the region of the cochlear nerve root: Golgi and Nissl methods, Neuroscience 7 (1982) 30133030.

[203] L.P. Tolbert, D.K. Morest, The neuronal architecture of the anteroventral cochlear nucleus of the cat in the region of the cochlear 
nerve root: electron microscopy, Neuroscience 7 (1982) 3053-3067.

[204] L.P. Tolbert, D.K. Morest, D.A. Yurgelun-Todd, The neuronal architecture of the anteroventral cochlear nucleus of the cat in the region of the cochlear nerve root: horseradish peroxidase labelling of identified cell types, Neuroscience 7 (1982) 3031-3052.

[205] H.H. Treeck, W. Pirsig, Differentiation of nerve endings in the cochlear nucleus on morphological and experimental basis, Acta Otolaryngol. 87 (1979) 47-60.

[206] D.R. Trune, Influence of neonatal cochlear removal on the development of mouse cochlear nucleus: I. Number, size, and density of its neurons, J. Comp. Neurol. 209 (1982) 409-424.

[207] L.O. Trussell, Synaptic mechanisms for coding timing in auditory neurons, Annu. Rev. Physiol. 61 (1999) 497-519.

[208] J. Tsuji, M.C. Liberman, Intracellular labeling of auditory nerve fibers in guinea pig: central and peripheral projections, J. Comp. Neurol. 381 (1997) 188-202.

[209] D.L. Tucci, D.E. Born, E.W. Rubel, Changes in spontaneous activity and CNS morphology associated with conductive and sensorineural hearing loss in chickens, Ann. Otol. Rhinol. Laryngol. 96 (1987) $343-350$

[210] R. Turecek, L.O. Trussell, Control of synaptic depression by glutamate transporters, J. Neurosci. 20 (2000) 2054-2063.

[211] H. Wagner, T.T. Takahashi, Influence of temporal cues on acoustic motion-direction sensitivity of auditory neurons in the owl, J. Neurophysiol. 68 (1992) 2063-2076.

[212] X. Wang, M.B. Sachs, Neural encoding of single-formant stimuli in the cat. I. Responses of the auditory nerve fibers, J. Neurophysiol. 70 (1993) 1054-1075.

[213] Y.-X. Wang, R.J. Wenthold, O.P. Ottersen, R.S. Petralia, Endbulb synapses in the anteroventral cochlear nucleus express a specific subset of AMPA-type glutamate receptor subunits, J. Neurosci. 18 (1998) 1148-1160.

[214] M.E. Warchol, P. Dallos, Neural coding in the chick cochlear nucleus, J. Comp. Physiol. A 166 (1990) 721-734.

[215] D.L. Weedman, T. Pongstaporn, D.K. Ryugo, Ultrastructural study of the granule cell domain of the cochlear nucleus in rats: Mossy fiber endings and their targets, J. Comp. Neurol. 369 (1996) 345360.

[216] R.J. Weinberg, A. Rustioni, A cuneocochlear pathway in the rat, Neuroscience 20 (1987) 209-219.

[217] R.J. Wenthold, C. Hunter, R.S. Petralia, Excitatory amino acid receptors in the rat cochlear nucleus, in: E. Mugnaini (Ed.), The Mammalian Cochlear Nuclei: Organization and Function, Plenum Press, New York, 1993, pp. 179-194.

[218] D.D. Wright, C.D. Blackstone, R.L. Huganir, D.K. Ryugo, Immunocytochemical localization of the mGluR $1 \alpha$ metabotropic glutamate receptor in the dorsal cochlear nucleus, J. Comp. Neurol. 364 (1996) 729-745.
[219] D.D. Wright, D.K. Ryugo, Mossy fiber projections from the cuneate nucleus to the cochlear nucleus in the rat, J. Comp. Neurol. 365 (1996) 159-172.

[220] W. Yan, N. Suga, Corticofugal modulation of the midbrain frequency map in the bat auditory system, Nat. Neurosci. 1 (1998) 54-58.

[221] Y. Ye, D.G. Machado, D.O. Kim, Projection of the marginal shell of the anteroventral cochlear nucleus to olivocochlear neurons in the cat, J. Comp. Neurol. 420 (2000) 127-138.

[222] E.D. Young, I. Nelken, R.A. Conley, Somatosensory effects on neurons in dorsal cochlear nucleus, J. Neurophysiol. 73 (1995) 743-765.

[223] E.D. Young, M.B. Sachs, Representation of steady-state vowels in the temporal aspects of the discharge patterns of populations of auditory-nerve fibers, J. Acoust. Soc. Am. 66 (1979) 13811403.

[224] E.D. Young, W.P. Shofner, J.A. White, J.-M. Robert, H.F. Voigt, Response properties of cochlear nucleus neurons in relationship to physiological mechanisms, in: W.M. Cowan (Ed.), Auditory Function: Neurobiological Bases of Hearing, Wiley, New York, 1988, pp. 277-312.

[225] S. Zhang, L.O. Trussell, Voltage clamp analysis of excitatory synaptic transmission in the avian nucleus magnocellularis, J. Physiol 480 (1994) 123-136.

[226] N. Zhou, T.N. Parks, Developmental changes in the effects of drugs acting at NMDA or non-NMDA receptors on synaptic transmission in the chick cochlear nucleus (nuc. Magnocellularis), Dev. Brain Res. 67 (1992) 145-167.

[227] N. Zhou, T.N. Parks, $\gamma$-D-glutamylaminomethyl sulfonic acid (GAMS) distinguishes subtypes of glutamate receptor in the chick cochlear nucleus (nuc. magnocellularis), Hear. Res. 60 (1992) 2026.

[228] N. Zhou, D.A. Taylor, T.N. Parks, Cobalt-permeable non-NMDA receptors in developing chick brainstem auditory nuclei, Neuroreport 6 (1995) 2273-2276.

[229] L. Zirpel, M.A. Janowiak, D.A. Taylor, T.N. Parks, Developmental changes in metabotropic glutamate receptor-mediated calcium homeostasis, J. Comp. Neurol. 421 (2000) 95-106.

[230] L. Zirpel, M.A. Janowiak, C.A. Veltri, T.N. Parks, AMPA receptor-mediated, calcium-dependent CREB phosphorylation in a subpopulation of auditory neurons surviving activity deprivation, J. Neurosci. 20 (2000) 6267-6275.

[231] L. Zirpel, W.R. Lippe, E.W. Rubel, Activity-dependent regulation of intracellular calcium in avian cochlear nucleus neurons: roles of protein kinases $\mathrm{A}$ and $\mathrm{C}$ and correlation with cell death, J. Neurophysiol. 79 (1998) 2288-2302.

[232] L. Zirpel, T.N. Parks, Zinc inhibition of Group I mGluR-mediated calcium homeostasis in auditory neurons, JARO 2 (2001) 180187. 